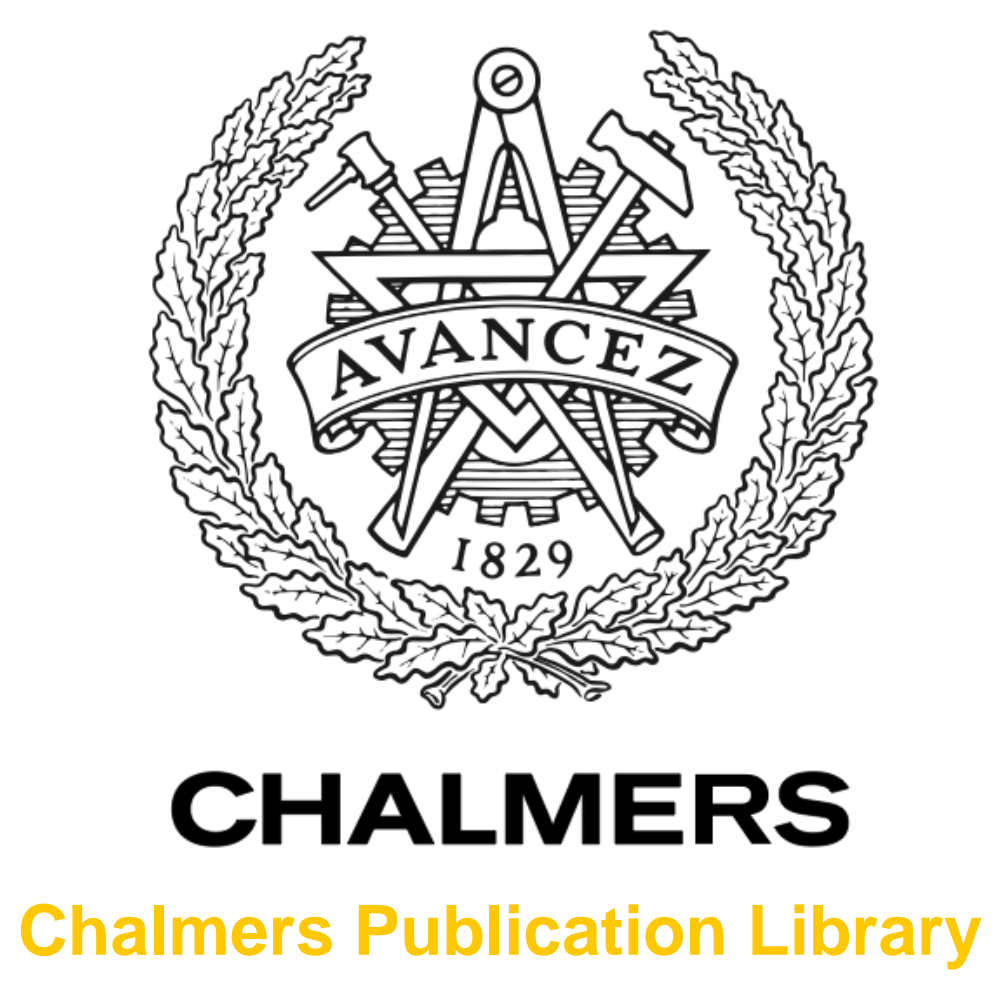

\title{
Sulfur Tolerance of CaxMn1-yMyO3 (M = Mg, Ti) Perovskite-Type Oxygen Carriers in Chemical-Looping with Oxygen Uncoupling (CLOU)
}

This document has been downloaded from Chalmers Publication Library (CPL). It is the author's version of a work that was accepted for publication in:

Energy \& Fuels (ISSN: 0887-0624)

Citation for the published paper:

Arjmand, M. ; Kooiman, R. ; Rydén, M. (2014) "Sulfur Tolerance of CaxMn1-yMyO3 (M = $\mathrm{Mg}, \mathrm{Ti})$ Perovskite-Type Oxygen Carriers in Chemical-Looping with Oxygen Uncoupling (CLOU)". Energy \& Fuels, vol. 28(2), pp. 1312â1324.

http://dx.doi.org/10.1021/ef402383v

Downloaded from: http://publications.lib.chalmers.se/publication/193522

Notice: Changes introduced as a result of publishing processes such as copy-editing and formatting may not be reflected in this document. For a definitive version of this work, please refer to the published source. Please note that access to the published version might require a subscription. 


\section{Sulphur Tolerance of $\mathrm{Ca}_{\mathrm{x}} \mathrm{Mn}_{1-\mathrm{y}} \mathrm{M}_{\mathrm{y}} \mathrm{O}_{3-\delta}(\mathrm{M}=\mathrm{Mg}$, Ti) Perovskite-type Oxygen Carriers in Chemical-Looping with Oxygen Uncoupling (CLOU)}

Mehdi Arjmand ${ }^{a,{ }^{*}}$, Roeland F. Kooiman ${ }^{b}$, Magnus Rydén ${ }^{c}$, Henrik Leion ${ }^{a}$, Tobias Mattisson ${ }^{c}$, Anders Lyngfelt ${ }^{c}$

${ }^{a}$ Department of Chemical and Biological Engineering, Division of Environmental Inorganic Chemistry, Chalmers University of Technology, SE-412 96 Göteborg, Sweden

${ }^{b}$ Department of Chemical Engineering and Chemistry, Eindhoven University of Technology, NL-5600MB, Eindhoven, the Netherlands

${ }^{c}$ Department of Energy and Environment, Division of Energy Technology, Chalmers University of Technology, SE-412 96 Göteborg, Sweden

\footnotetext{
* To whom correspondence should be addressed. Telephone: +46-31-772-2822;

E-mail: arjmand@chalmers.se
} 


\begin{abstract}
Perovskite-structured oxygen carriers of the type $\mathrm{Ca}_{\mathrm{x}} \mathrm{Mn}_{1-\mathrm{y}} \mathrm{M}_{\mathrm{y}} \mathrm{O}_{3-\delta}(\mathrm{M}=\mathrm{Mg}$, Ti) have been investigated for the CLOU process. The oxygen carrier particles were produced by spray drying and were calcined at $1300^{\circ} \mathrm{C}$ for $4 \mathrm{~h}$. A batch fluidized-bed reactor was used to investigate the chemical-looping characteristics of the materials. The effect of calcium content, dopants (Mg and $\mathrm{Ti})$ and operating temperature $\left(900,950,1000\right.$ and $\left.1050^{\circ} \mathrm{C}\right)$ on the oxygen uncoupling property and the reactivity with $\mathrm{CH}_{4}$ in presence and absence of $\mathrm{SO}_{2}$ was evaluated. In addition, the attrition resistance and mechanical integrity of the oxygen carriers were examined in a jet-cup attrition rig. All of the investigated perovskite-type materials were able to release gas phase oxygen in inert atmosphere. Their reactivity with methane was high and increased with temperature and calcium content, approaching complete gas yield at $1000^{\circ} \mathrm{C}$. The reactivity decreased in the presence of $\mathrm{SO}_{2}$ for all of the investigated oxygen carriers. Decreasing the calcium content resulted in a less severe decrease in reactivity in the presence of $\mathrm{SO}_{2}$, with the exception of materials doped with both $\mathrm{Mg}$ and $\mathrm{Ti}$, for which a higher resistance to sulphur deactivation could be maintained even at higher calcium contents. The drop in reactivity in the presence of $\mathrm{SO}_{2}$ also decreased at higher temperatures and at $1050^{\circ} \mathrm{C}$, the decrease in the reactivity of the $\mathrm{Mg}$ - and Ti-doped material was minimal. Sulphur balance over the reactor system indicated that the fraction of the introduced $\mathrm{SO}_{2}$ that passed through the reactor increased with temperature. It was shown that it is possible to regenerate the oxygen carriers during reduction in the absence of $\mathrm{SO}_{2}$. Most of the materials also showed relatively low attrition rates. The results indicate that it is possible to modify the operating conditions and properties of perovskite-type oxygen carriers to decrease or avoid their deactivation by sulphur.
\end{abstract}

Keywords: $\mathrm{CO}_{2}$-capture; chemical-looping combustion (CLC); chemical-looping with oxygen uncoupling (CLOU); oxygen carrier; perovskite-structured, sulphur deactivation. 


\section{Introduction}

The chemical-looping combustion (CLC) and chemical-looping with oxygen uncoupling (CLOU) are innovative processes for efficient combustion of hydrocarbon fuels with inherent separation of carbon dioxide. ${ }^{1-3}$ Chemical-looping has the great advantage of capturing $\mathrm{CO}_{2}$ without the energy and cost penalties resulting from gas separation, which cannot be avoided in other $\mathrm{CO}_{2}$ capture technologies. ${ }^{2,4,5}$ Until now, CLC has been successfully demonstrated in a number of units of sizes up to $120 \mathrm{~kW}^{6}$ and reviews of current achievements in CLC are given by Lyngfelt, ${ }^{6-8}$ Hossain and de Lasa ${ }^{9}$, Adanez et al. ${ }^{10}$ and Fan et al. ${ }^{11}$

In the fuel reactor of a chemical-looping system, a gas-solid reaction is preferred over a solidsolid reaction due to the much faster reaction rates. This is particularly important with respect to applications for solid fuels, which means that solid fuels must be gasified initially with steam or $\mathrm{CO}_{2}$ to produce $\mathrm{CO}$ and $\mathrm{H}_{2}$ gases which can then react with the solid oxygen carrier material. ${ }^{12-16}$ Since the gasification of a solid fuel is a rather slow process, the gasification step in CLC becomes the rate-determining step in the overall process. Therefore, another technique can be used for solid fuels which is called chemical-looping with oxygen uncoupling (CLOU). ${ }^{17}$ In CLOU, the oxygen carrier releases gaseous oxygen which can then react directly with the solid fuel as in normal combustion. For this reason, the gasification process can be avoided in CLOU. The source of the gaseous oxygen in CLOU is the oxygen carrier material. Demonstration of the CLOU process ${ }^{18}$ has proven the advantage of this technology over the CLC process, where slow gasification is an imperative step. ${ }^{19}$ Moreover, the solids inventory in the fuel reactor of the CLOU process would be lower than in CLC due to faster fuel conversion, ${ }^{20}$ thus limiting the need for a carbon stripper or additional treatments. In CLOU, thermodynamic equilibrium governs the uncoupling of gaseous oxygen from the oxygen carrier and the subsequent oxidation of the reduced oxygen carrier to its initial state in the air reactor. Therefore, a required property for the oxygen carrier in CLOU is that it must be able to both react with $\mathrm{O}_{2}$ (oxidize) and release $\mathrm{O}_{2}$ at temperatures suitable for the process, i.e. 800 to $1200^{\circ} \mathrm{C}$.

The $\mathrm{CuO}-\mathrm{Cu}_{2} \mathrm{O}$ oxide pair is one of the prominent monometallic oxygen carriers suitable for the CLOU process, along with $\mathrm{Mn}_{2} \mathrm{O}_{3}-\mathrm{Mn}_{3} \mathrm{O}_{4}$ and $\mathrm{CoO}-\mathrm{Co}_{3} \mathrm{O}_{4}$ oxide pairs. ${ }^{21-23}$ For pure $\mathrm{Mn}_{2} \mathrm{O}_{3}-\mathrm{Mn}_{3} \mathrm{O}_{4}$, reoxidation is restricted to lower temperatures (below $800^{\circ} \mathrm{C}$ ), which are of less practical importance for a realistic CLC unit. It is however possible to overcome this thermodynamic constraint by combining manganese oxide with other oxides, for instance $\mathrm{Ni}$, $\mathrm{Cu}, \mathrm{Si}, \mathrm{Mg}, \mathrm{Si}, \mathrm{Fe}^{21-23}$ Co-based oxygen carriers are however, less attractive due to cost, 
health and environmental issues. A third group of manufactured oxygen carriers suitable for the CLOU process are $\mathrm{ABO}_{3}$ perovskite-type materials. ${ }^{24-34}$ These materials can release a significant amount of oxygen through,

$$
A B O_{(3-\delta)_{A R}} \leftrightarrow A B O_{(3-\delta)_{F R}}+\frac{1}{2}\left(\delta_{F R}-\delta_{A R}\right) O_{2}
$$

Here $\delta$ is the degree of oxygen non-stoichiometry in the perovskite-structured material and $\mathrm{AR}$ and FR refer to the value of $\delta$ in the air and the fuel reactor, respectively. The amount of oxygen that can be released or taken up depends on the oxygen partial pressure and the temperature in the fuel and the air reactors. The A- and the B-sites can also be doped or substituted with other elements, and thus a number of different perovskites can be synthesized. One promising group of perovskite-type oxygen carrier materials belongs to the calcium manganate $\left(\mathrm{CaMnO}_{3-\delta}\right)$ family and its slightly altered variants, which have shown excellent behaviour for gaseous fuel combustion in continuous operation. ${ }^{35,36}$ It has also been reported that doping at the A- and/or B-sites can significantly affect the oxygen-carrying capacity, performance, reactivity and stability of the oxygen carrier. ${ }^{24}$

Using perovskite-type oxygen carriers in CLC or CLOU is not without limitations. Sulphur is present in significant concentrations in solid fuels and to a lesser extent in natural gas. Several studies have investigated the use of perovskite-structured materials in fuel cell applications and have found that these oxides can be highly susceptible to deactivation in the presence of sulphur-containing compounds. ${ }^{37-42}$ The general consensus is that the deactivation of these materials by $\mathrm{SO}_{2}$ or $\mathrm{H}_{2} \mathrm{~S}$ occurs in two steps. Initially, the sulphur-containing species binds or adsorbs to certain active sites by pairing with oxygen ion vacancies. Then, the adsorbed sulphur species is converted to sulphite (e.g. $\mathrm{CaSO}_{3}$ or $\mathrm{LaSO}_{3}$ ) and after that to a sulphate species (e.g. $\mathrm{CaSO}_{4}$ or $\mathrm{LaSO}_{4}$ ). ${ }^{43}$ Severe deactivation of perovskite-type materials have been reported after exposure to even small amounts of $\mathrm{SO}_{2}$ which has been ascribed to phase separation and the formation of sulphates. ${ }^{39-42}$ Substitution with transition metal elements such as $\mathrm{Ti}, \mathrm{Zr}, \mathrm{V}, \mathrm{Sn}, \mathrm{Cu}$ or $\mathrm{Cr}$ might make the $\mathrm{SO}_{2}$ bonding with the surface weaker, and therefore could result in higher resistance to $\mathrm{SO}_{2}$ poisoning. ${ }^{43,44}$ For instance, the presence of $\mathrm{Mn}$ at the $\mathrm{B}$ site increases the reactivity for methane conversion but makes such materials more prone to poisoning by $\mathrm{SO}_{2}$, while the presence of $\mathrm{Cr}$ at the $\mathrm{B}$ site decreases the former and increases the latter, owing to the acidic nature of $\mathrm{Cr}^{38}$ Moreover, the addition of $\mathrm{MgO}$ to such materials could slow the deactivation process, as $\mathrm{MgO}$ preferentially reacts with sulphur, thus allowing the perovskite-structured material to avoid deactivation for a longer period of 
time. ${ }^{45}$ It should be mentioned however, that operating conditions such as oxygen partial pressures and/or temperatures in CLC or CLOU are substantially different from those encountered in fuel cell applications, which necessitates additional research on this matter.

Predicting the behaviour of $\mathrm{CaMnO}_{3-\delta}$ during the chemical-looping combustion of sulphurcontaining fuels is not a trivial task. Earlier studies on the use of limestone $\left(\mathrm{CaCO}_{3}\right)$ in fluidized-bed combustion (FBC) for capturing $\mathrm{SO}_{2}$ provide some information on the possible reaction pathways in the system $\mathrm{Ca}-\mathrm{S}-\mathrm{O}$ under oxidizing and reducing conditions, ${ }^{46-48}$ which are summarized in Table 1. It is possible to envisage the occurrence of similar reactions in the fuel and the air reactor of a CLC or CLOU unit for perovskite-type oxygen carriers should calcium in a perovskite-structured material form $\mathrm{CaSO}_{4}$ or $\mathrm{CaS}$. Of particular importance in Table 1 are the decomposition reactions of $\mathrm{CaSO}_{4}$ under reducing conditions, i.e. equations (5)-(7), which indicate that $\mathrm{CaSO}_{4}$ is not stable under reducing conditions.

Figure 1 shows the stability regions of $\mathrm{CaS}, \mathrm{CaO}$ and $\mathrm{CaSO}_{4}$ as a function of temperature and partial pressure of $\mathrm{O}_{2}$ and $\mathrm{SO}_{2}$ using FactSage ${ }^{\circledR}$ 6.3.1. ${ }^{49}$ It can be readily seen that $\mathrm{CaO}$ is thermodynamically more stable than $\mathrm{CaSO}_{4}$ and $\mathrm{CaS}$ at certain partial pressures of $\mathrm{O}_{2}$ and $\mathrm{SO}_{2}$. Worth noting is that the stable region for $\mathrm{CaO}$ increases with temperature, thus favouring the decomposition of $\mathrm{CaSO}_{4}$ or $\mathrm{CaS}$.

Figure 1 would be slightly different if $\mathrm{CaMnO}_{3-\delta}$ was replaced with $\mathrm{CaO}$. While precise thermodynamic data on the $\mathrm{CaMnO}_{3-\delta}$ perovskite-structured materials is lacking, it is helpful to consider $\mathrm{CaMnO}_{3-\delta}$ as being composed of the two individual components $\mathrm{CaO}$ and $\mathrm{MnO}_{2-\delta}$. It is known that a mixture of calcium and manganese oxides of the correct stoichiometry spontaneously forms perovskite-type materials during calcination, at least above $1000^{\circ} \mathrm{C}$. This indicates that $\mathrm{CaMnO}_{3-\delta}$ is more strongly favoured thermodynamically at these temperatures than calcium and manganese oxides. Considering that manganese oxides are inert to sulphur species at these temperatures, it is expected that the window of operation without the formation of solid sulphur compounds should be larger for $\mathrm{CaMnO}_{3-\delta}$ than for $\mathrm{CaO}$.

Research on the tolerance of perovskite-type oxygen carriers to sulphur deactivation in CLC or CLOU is very limited. Reactivity testing with $\mathrm{CaMn}_{0.875} \mathrm{Ti}_{0.125} \mathrm{O}_{3-\delta}$ as oxygen carrier using $\mathrm{CH}_{4}$ at $950^{\circ} \mathrm{C}$ in the presence of $\mathrm{SO}_{2}$ has suggested a decrease in reactivity, most likely due to the formation of $\mathrm{CaSO}_{4}{ }^{50}$ The aim of this study is to investigate the sulphur tolerance of different calcium-manganese-based oxygen carriers in CLOU. The effect of the calcium content, dopants $(\mathrm{Mg}$ and $\mathrm{Ti})$ and the effect of operating temperature (900, 950, 1000 and $1050^{\circ} \mathrm{C}$ ) on the oxygen uncoupling property and the reactivity of oxygen carriers with 
methane has been evaluated. In addition, the mechanical and attrition resistance of the oxygen carriers has been evaluated in a jet-cup attrition rig. To investigate the influence of sulphur on reactivity of oxygen carriers and their oxygen release ability, the oxygen carrier particles have been exposed to $\mathrm{SO}_{2}$ during reduction, to simulate the sulphur that would be released from sulphur-containing solid fuels. Using an overall mass balance over the reactor system for sulphur, it has been possible to evaluate the sulphur tolerance and the degree of sulphur deactivation of the investigated materials.

\section{Experimental}

\subsection{Preparation and fabrication of the oxygen carriers}

The oxygen carriers prepared in this investigation are summarized in Table 2. The particles were manufactured by spray-drying at VITO (Flemish Institute for Technological Research, Belgium) using the intended combination of $\mathrm{Mn}_{3} \mathrm{O}_{4}$ (Trimanox, Chemalloy), $\mathrm{Ca}(\mathrm{OH})_{2}$ (Nordkalk), $\mathrm{MgO}$ (MagChem 30, Martin Marietta Magnesia Specialties) and $\mathrm{TiO}_{2}$ (Alfa Aesar). Details of the spray drying technique can be found elsewhere. ${ }^{32,51}$ The spray-dried particles were calcined at $1300^{\circ} \mathrm{C}$ for $4 \mathrm{~h}$ and were then sieved through stainless steel screens to yield particles in the range of 125-180 and 180-250 $\mu \mathrm{m}$.

\subsection{Characterization of the oxygen carriers}

The crystalline phases of the oxygen carriers were identified using powder X-ray diffraction (Bruker AXS, D8 Advanced) with $\mathrm{CuK}_{\alpha 1}$ radiation. The bulk (tapped) density was obtained for particles in the size range of $125-180 \mu \mathrm{m}$ with a graduated cylinder and a scale. The Brunauer-Emmett-Teller (BET) specific surface area was determined using $\mathrm{N}_{2}$-adsorption (Micromeritics, TriStar 3000). The crushing strength, i.e. the force needed to fracture a single particle, was measured by using a digital force gauge (Shimpo, FGN-5) for particles in the size range of 180-250 $\mu \mathrm{m} .30$ measurements were made of each sample and the average value was chosen as the representative crushing strength. The morphology of the particles was examined with an environmental scanning electron microscope (ESEM) fitted with a field emission gun (FEI, Quanta 200) and energy-dispersive X-ray (EDX).

In order to assess the oxygen capacity $\left(R_{O}\right)$ of the investigated materials for CLOU, a thermogravimetric analyser (Netzsch, STA 409 PC Luxx) was used. Approximately $20 \mathrm{mg}$ of a used sample $(125-180 \mu \mathrm{m})$ from the reactivity experiment in the fluidized-bed rector following oxidation in $5 \% \mathrm{O}_{2}$ was used. The sample was exposed to high purity $\mathrm{N}_{2}$ with an inlet flow rate of $20 \mathrm{~mL} / \mathrm{min}$. The heating rate was a linear ramp of $40^{\circ} \mathrm{C} / \mathrm{min}$ and after 
reaching $1000^{\circ} \mathrm{C}$, the temperature was maintained constant for $30 \mathrm{~min}$. Prior to this, the thermobalance was calibrated with an empty $\mathrm{Al}_{2} \mathrm{O}_{3}$ crucible under identical experimental conditions.

The attrition rate of the particles sized 125-180 $\mu \mathrm{m}$ was measured using a customized jet-cup attrition rig, ${ }^{52}$ which simulates the effects of grid jet attrition and cyclone attrition in a circulating fluidized-bed combustor, details of which can be found elsewhere. ${ }^{24,51}$

\subsection{Experimental setup and procedure in the fluidized-bed reactor}

A laboratory-scale fluidized-bed reactor system was used for examining the oxygen uncoupling behaviour and the reactivity of the oxygen carriers. A more detailed description of the reactor system has been presented previously. ${ }^{24,51,53,54}$ In order to obtain an understanding of the degree of deactivation of perovskite-structured oxygen carriers, a mass balance for sulphur must be made over the reactor system. However, a major difficulty arose due to the high solubility of $\mathrm{SO}_{2}$ in water ${ }^{55}$ resulting in the partial loss of $\mathrm{SO}_{2}$ in the condensed water produced from the conversion of methane during reduction. In the previously used experimental setups, ${ }^{24,53,54}$ the exit gas stream from the reactor was led into a condenser to remove the water formed during the conversion of methane. In the present study, the condenser was replaced with a filter pipe directly after the sampling probe, followed by a short heated line. The filter was filled with granulated magnesium perchlorate anhydrous $\left(\mathrm{Mg}\left(\mathrm{ClO}_{4}\right)_{2}\right)$ as the drying agent in order to dry the effluent stream. Thus, $\mathrm{SO}_{2}$ was prevented from dissolving in the water produced during the conversion of methane.

A summary of the experimental procedure is outlined in Table 3. Initially, the reactivity and the oxygen release ability of the materials were investigated. Here, $15 \mathrm{~g}$ of the sample sized $125-180 \mu \mathrm{m}$ was placed on the porous plate and the reactor was heated to $900^{\circ} \mathrm{C}$ in $5 \% \mathrm{O}_{2^{-}}$ balance $\mathrm{N}_{2}$ mixture in order to fully oxidize the oxygen carrier. The rationale for using $5 \% \mathrm{O}_{2}$ was to determine whether the oxygen carrier could be oxidized in conditions similar to those at the outlet of the air reactor in a realistic CLC unit. Hereinafter, the term 'cycle' will be used to describe a sequence of reduction-oxidation periods. The reducing periods consisted of exposures to either an inert $\left(\mathrm{N}_{2}\right)$ or a fuel $\left(\mathrm{CH}_{4}\right)$ gas, followed by oxidation with the aforementioned $5 \% \mathrm{O}_{2}$ mixture. Fuel cycles with $50 \% \mathrm{CH}_{4}$-balance $\mathrm{N}_{2}$ for $20 \mathrm{~s}$ during the reduction period were conducted at the temperatures 900,950 and $1000^{\circ} \mathrm{C}$. Nitrogen was used as an inert purge gas for $60 \mathrm{~s}$ in between oxidation and reduction periods to avoid gases being mixed during the preceding reduction or the succeeding oxidation period. After the fuel 
cycles, inert $\left(\mathrm{N}_{2}\right)$ gas cycles were conducted at 900,950 and $1000^{\circ} \mathrm{C}$ for $360 \mathrm{~s}$, to investigate the oxygen release ability.

In order to investigate the tolerance of the oxygen carrier towards sulphur deactivation, the stream of $50 \% \mathrm{CH}_{4}$-balance $\mathrm{N}_{2}$ used in the reduction phase was substituted with a stream of $50 \% \mathrm{CH}_{4}-0.5 \% \mathrm{SO}_{2}$-balance $\mathrm{N}_{2}$. Thus, the concentration of $\mathrm{SO}_{2}$ in this stream corresponds to 5000 vppm which is representative of a low-sulphur coal. The fuel cycles were carried out in a similar way followed by inert $\left(\mathrm{N}_{2}\right)$ gas cycles, with the difference that the order of the experimental temperatures was 1000,950 and $900^{\circ} \mathrm{C}$. This was to minimize the deactivation process of the oxygen carriers by virtue of lower favourability of $\mathrm{CaSO}_{4}$ formation at higher temperatures, as shown in Figure 1.

To establish reproducibility of the results, all inert gas $\left(\mathrm{N}_{2}\right)$ cycles and fuel cycles in the absence of $\mathrm{SO}_{2}$ were repeated three times, while fuel cycles in the presence of $\mathrm{SO}_{2}$ were repeated five times. Thus, the performance of each oxygen carrier was evaluated for a total of 42 fuel and inert cycles. The flow rate was kept constant at $900 \mathrm{~mL}_{\mathrm{N}} / \mathrm{min}$ during reduction, inert and oxidation periods. This flow rate corresponded to a superficial gas velocity, $U$, in the reactor of approximately 9 to 21 and 12 to 26 times higher than the calculated minimum fluidization gas velocity, $U_{m f}$, of the oxygen carrier particles during reduction (with $50 \% \mathrm{CH}_{4}$ ) and inert $\left(\mathrm{N}_{2}\right)$ and oxidation periods $\left(5 \% \mathrm{O}_{2}\right)$, respectively. The minimum fluidization velocity, $U_{m f}$, was calculated using the correlation given by Kunii and Levenspiel. ${ }^{56}$ However, it should be noted that due to gas expansion during reduction, the actual velocity in the bed was higher, as one mole of $\mathrm{CH}_{4}$ can be converted to one mole of $\mathrm{CO}_{2}$ and two moles of $\mathrm{H}_{2} \mathrm{O}$.

\subsection{Data analysis}

When methane was used as the fuel, it was converted to $\mathrm{CO}, \mathrm{H}_{2}, \mathrm{H}_{2} \mathrm{O}$ and $\mathrm{CO}_{2}$ during the reduction period. The reactivity of a given oxygen carrier was quantified in terms of gas yield or conversion efficiency, $\gamma$, and was defined as the volume fraction, $y_{i}$, of fully oxidized fuel, $\mathrm{CO}_{2}$, divided by the sum of all the volume fractions of carbon containing gases, i.e. $\mathrm{CH}_{4}, \mathrm{CO}$ and $\mathrm{CO}_{2}$, in the outlet stream,

$$
\gamma_{\mathrm{CH}_{4}}=\frac{y_{\mathrm{CO}_{2}}}{y_{\mathrm{CO}_{2}}+y_{\mathrm{CH}_{4}}+y_{\mathrm{CO}}}
$$

Here, $y_{i}$ denotes the concentration (vol.\%) of each respective gas measured with the gas analyser. 
The oxygen carrying capacity, $R_{O}$, of the investigated carriers for CLOU is defined as the mass change of oxygen in the samples as follows:

$$
R_{O}=\frac{m_{o x}-m_{r e d}}{m_{o x}}
$$

where $m_{o x}$ and $m_{r e d}$ are the mass of the oxygen carrier in oxidized and reduced states, respectively.

The mass-based conversion of the oxygen carrier $\omega$ is defined as.

$$
\omega=\frac{m}{m_{o x}}
$$

where $m$ is the actual mass of the oxygen carrier in the reactor. Since it is not possible to measure the mass of the oxygen carrier in the reactor while cycling between different phases, a mass balance for oxygen has been made over the reactor system. Consequently, by measuring the concentrations of various gaseous species in the gas analyser, the mass-based conversion $\omega$ of the oxygen carrier can be calculated via

$$
\omega_{i}=1-\int_{t_{0}}^{t_{1}} \frac{\dot{n}_{\text {out }} M_{O}}{m_{o x}}\left(4 y_{\mathrm{CO}_{2}}+3 y_{C O}+2 y_{\mathrm{O}_{2}}-y_{\mathrm{H}_{2}}\right) d t
$$

where $\omega_{i}$ is the instantaneous mass-based conversion at time $t_{l}, \dot{n}_{\text {out }}$ is the molar flow rate of dry gas at the reactor outlet as measured by the analyser, $M_{O}$ is the molar mass of oxygen and $t_{0}$ and $t_{1}$ are the initial and final times of measurement.

In order to facilitate a comparison between different oxygen carriers at varying temperatures, $\gamma_{\mathrm{CH}_{4} \text {,ave }}$, has been used defined as the average of gas yield in Eq. (5) for the period of $\omega$ from 1 to 0.99 .

The total $\mathrm{SO}_{2}$ yield, $\eta_{\mathrm{SO}_{2}}$, due to the adsorption of sulphur and/or reaction with the oxygen carrier particles has been determined using a mass balance for $\mathrm{SO}_{2}$ over the reactor system via,

$$
\eta_{\mathrm{SO}_{2}}=\frac{n_{\mathrm{SO}_{2}, \text { out }}}{n_{\mathrm{SO}_{2}, \text { in }}}
$$

where $n_{\mathrm{SO}_{2}, \text { in }}$ are the moles of $\mathrm{SO}_{2}$ introduced to the reactor and $n_{\mathrm{SO}_{2}, \text { out }}$ are the moles of $\mathrm{SO}_{2}$ in the effluent during the entire cycle. Thus, $\eta_{\mathrm{SO}_{2}}=1$ indicates that all $\mathrm{SO}_{2}$ has passed through the reactor and is seen by the gas analyser, while $\eta_{\mathrm{SO}_{2}}=0$ implies that all $\mathrm{SO}_{2}$ has been absorbed by and/or reacted with the oxygen carrier particles. 


\section{Results and Discussion}

\subsection{Oxygen uncoupling of the oxygen carriers}

The oxygen uncoupling profile during an inert gas period is shown as an example in Figure 2 for C46MTMg at 900,950 and $1000^{\circ} \mathrm{C}$. An inert period at $900^{\circ} \mathrm{C}$ for sand particles has been included in this figure for comparison. Similar to C46MTMg, all investigated materials released a substantial amount of oxygen. In this particular case, the oxygen release increased with temperature. The oxygen released decreased steadily as a function of time due to the oxygen non-stoichiometry, $\delta$, being dependent on the defect chemistry and oxygen partial pressure in the ambient, according to Eq. (1), which is typical for perovskite-type materials. ${ }^{24}$, 29, 32, 33 There was little difference in the oxygen release profiles during cycling, indicating a stable oxygen uncoupling property for all materials.

To facilitate the comparison of the oxygen uncoupling property among the different investigated perovskite-type materials prior to and after fuel cycles in the presence and absence of $\mathrm{SO}_{2}$, an average oxygen concentration during the inert phase has been used in Figure 3. In order to avoid any influence on the results from the oxygen remaining in the reactor from the oxidation phase, the average oxygen concentration has been calculated for the inert phase starting from $100 \mathrm{~s}$ into the inert period and until the end of the period. The ten perovskite-type oxygen carriers have been categorized into three different groups, namely undoped, doped with $\mathrm{Mg}$ and doped with $\mathrm{Mg}$ and $\mathrm{Ti}$, all three groups contained materials with different calcium content. It can be observed in Figure 2 that all of the investigated perovskite-structured materials were able to release oxygen and therefore have CLOU ability. During inert periods following the fuel cycles in the absence of $\mathrm{SO}_{2}$, the undoped and the $\mathrm{Mg}$ doped materials showed the same trend of an increase in the average oxygen concentration with a rise in the temperature from 900 to $950^{\circ} \mathrm{C}$. However, for both of these materials, the average oxygen concentration at $1000^{\circ} \mathrm{C}$ fell below that at $900^{\circ} \mathrm{C}$, suggesting that it was not possible to fully oxidize these materials at $1000^{\circ} \mathrm{C}$. The materials doped with both $\mathrm{Mg}$ and $\mathrm{Ti}$ showed an increase in the average oxygen concentration with a rise in temperature from 900 to $1000^{\circ} \mathrm{C}$.

It can also be seen that, in general, lowering the calcium content in the perovskite-type materials decreased the average oxygen concentration during the inert periods. In the inert periods following reduction in the presence of $\mathrm{SO}_{2}$, all perovskite-type materials showed an increase in average oxygen concentration in the inert period with a rise in temperature. 
However, for undoped and Mg-doped materials, the average oxygen concentrations were considerably lower than the inert periods following a reduction in the absence of $\mathrm{SO}_{2}$. Thus, it can be inferred that $\mathrm{SO}_{2}$ had degraded the oxygen uncoupling properties of the investigated materials. Materials doped with both $\mathrm{Mg}$ and Ti materials showed no substantial difference in the average oxygen concentration following reduction in the presence of $\mathrm{SO}_{2}$.

\subsection{Reactivity of the oxygen carriers}

Figure 4 shows a typical gas concentration and temperature profile during the third reduction and following oxidation periods at $1000^{\circ} \mathrm{C}$ for the $\mathrm{C} 43 \mathrm{MMg}$ oxygen carrier with $50 \% \mathrm{CH}_{4}$ balance $\mathrm{N}_{2}$. Initially, the carrier was oxidized in $5 \% \mathrm{O}_{2}$, however, when it was shifted to the inert $\left(\mathrm{N}_{2}\right)$ period, the oxygen concentration decreased steadily in the same way as shown in Figure 4 for the oxygen uncoupling tests. Upon fuel addition, the $\mathrm{CO}_{2}$ evolved as methane was converted, while the oxygen concentration decreased to zero. After the complete conversion of fuel in the early part of the reduction period, some $\mathrm{CH}_{4}$ and $\mathrm{CO}$ could be detected. There was a slight increase in temperature during the reduction period and a greater increase in temperature during the oxidation period as a result of the overall exothermicity of the occurring reactions. As shown previously, ${ }^{24}$ the reduction of similar perovskite-structured materials caused by methane has occurred by means of a combination of two reactions: (1) direct reaction of methane with the solid particles (via CLC), and (2) the reaction of methane with the gaseous oxygen released from the carrier (via CLOU).

A large of number of chemical reactions could be written for the $\mathrm{SO}_{2}-\mathrm{CH}_{4}-\mathrm{O}_{2}$ reaction system. Preliminary equilibrium calculations using HSC Chemistry ${ }^{\circledR}$ (ver. 5.11) ${ }^{57}$ indicates that under the experimental conditions used in this investigation, i.e. the sub-stoichiometric combustion of $\mathrm{CH}_{4}$ in the presence of $\mathrm{SO}_{2}, \mathrm{H}_{2} \mathrm{~S}$ should be formed. Therefore several basic experiments were carried out to investigate the reactions that may possibly occur, the products of the $\mathrm{SO}_{2}-\mathrm{CH}_{4}-\mathrm{O}_{2}$ reaction system, and to ensure that a mass balance for sulphur over the reactor system could be obtained. Initially, the absence of homogenous reactions in the system or any influence from the reactor system was confirmed by passing the $0.5 \% \mathrm{SO}_{2}$ and $50 \%$ $\mathrm{CH}_{4}$-balance $\mathrm{N}_{2}$ feeding gas mixture through a reactor without a bed of oxygen carrier particles at $950^{\circ} \mathrm{C}$. Following this, a set of experiments with partial and complete combustion of methane in the presence of $\mathrm{SO}_{2}$ at temperatures of 900 and $1000^{\circ} \mathrm{C}$ was performed using an empty reactor. In this set of experiments, oxygen was added to the feeding gas mixture in stoichiometric and sub-stoichiometric conditions to emulate oxygen release from the particles. The rationale for this experiment was to investigate whether reduced sulphur compounds such 
as $\mathrm{COS}, \mathrm{H}_{2} \mathrm{~S}$ or $\mathrm{S}$ could be formed by means of gas-phase reactions, which would need to be taken into account in the sulphur mass balance. Therefore, it would be possible to confirm whether the loss of sulphur in the effluent was due to the formation of reduced sulphur species or due to a reaction with the actual perovskite-structured material. No reduced sulphur species were found when running the experiment in an empty reactor since all $\mathrm{SO}_{2}$ introduced to the reactor was detected by the analyser in the form of $\mathrm{SO}_{2}$, meaning that a $100 \%$ mass balance for sulphur could be achieved.

It has also been reported that perovskite-type materials possess catalytic activity for the reduction of $\mathrm{SO}_{2}$ to $\mathrm{H}_{2} \mathrm{~S}, \mathrm{COS}$ and $\mathrm{S}$ in the presence of a reducing gas such as methane. ${ }^{58,59} \mathrm{In}$ order to examine whether reduced sulphur species may form in the presence of the investigated materials, several preliminary reactivity cycles were carried out. To do this, the gas following the first filter filled with $\mathrm{Mg}\left(\mathrm{ClO}_{4}\right)_{2}$ as the drying agent was led into another heated oven at $900^{\circ} \mathrm{C}$ where additional oxygen was provided to oxidize all the compounds to their fully oxidized state. This meant that the remaining unconverted $\mathrm{CO}$ and $\mathrm{CH}_{4}$ as well as any reduced sulphur species that may had been produced as a result of the bed material's catalytic activity for the reduction of $\mathrm{SO}_{2}$, would be oxidized to $\mathrm{CO}_{2}, \mathrm{H}_{2} \mathrm{O}$ and $\mathrm{SO}_{2}$. An additional filter with $\mathrm{Mg}\left(\mathrm{ClO}_{4}\right)_{2}$ as the drying agent was also placed after this second oxidation step. By-pass mechanisms using two-way valves allowed bypassing the second oxidation step and therefore leading the effluent gas from the reactor directly to the analyser. Thus, a fuel cycle with $50 \% \mathrm{CH}_{4}$ and $0.5 \% \mathrm{SO}_{2}$-balance $\mathrm{N}_{2}$ was performed using the $\mathrm{C} 45 \mathrm{M}$ 1300 oxygen carrier at both 900 and $1000^{\circ} \mathrm{C}$. The total $\mathrm{SO}_{2}$ yield was measured in two different ways: (1) through the second heated oven, and (2) through bypassing the second oven and leading the off-gas directly to the analyser. The total $\mathrm{SO}_{2}$ yield was determined by integrating the area under the $\mathrm{SO}_{2}$ curve. The total $\mathrm{SO}_{2}$ yield was the same in both cases and at both temperatures which indicated that reduced sulphur species were not created during the reduction phase, even in the presence of a perovskite-type oxygen carrier in the bed. Consequently, the second oxidation step was omitted in the remainder of the reactivity tests.

Figure 5 shows the concentration and temperature profiles for $\mathrm{C} 43 \mathrm{MMg}$ during the fifth fuel cycle with $50 \% \mathrm{CH}_{4}$ and $0.5 \% \mathrm{SO}_{2}$-balance $\mathrm{N}_{2}$ at $1000^{\circ} \mathrm{C}$. By comparing Figure 5 with Figure 4 , it can be seen that less methane had been converted, as shown by the lower $\mathrm{CO}_{2}$ and higher $\mathrm{CH}_{4}$ peaks when the oxygen carrier was exposed to $\mathrm{SO}_{2}$ during the reduction phase. Only a small fraction of $\mathrm{SO}_{2}$ had passed through the reactor during the reduction period, whereas in the subsequent inert and oxidation periods, more $\mathrm{SO}_{2}$ was found in the off-gas. The oxidation 
time until stable oxygen concentration (5\%) was reached, was also shorter for the experiment in the presence of $\mathrm{SO}_{2}$ than in the experiment with the absence of $\mathrm{SO}_{2}$. This can be explained by the fact that more oxygen was consumed during the reduction of the material when $\mathrm{SO}_{2}$ was absent than when the oxygen carrier was reduced in the presence of $\mathrm{SO}_{2}$, likely due to deactivation of the oxygen carrier in the latter case. Possible mechanisms for the reaction of sulphur with the investigated perovskite-type oxygen carriers are discussed in Section 3.3.

Figure 6 shows the gas average gas yield, $\gamma_{\mathrm{CH}_{4} \text {,ave }}$, and total $\mathrm{SO}_{2}$ yield, $\eta_{\mathrm{SO}_{2}}$, as a function of temperature during fuel cycles in the presence of $\mathrm{SO}_{2}$ for $\mathrm{C} 40 \mathrm{MTMg}$ at 900,950 and $1000^{\circ} \mathrm{C}$. It can be noted that there was a slight decrease in reactivity after every cycle. It was shown previously that a significant number of fuel cycles $(\sim 30)$ must be carried out in order to observe a significant decrease in reactivity caused by sulphur deactivation. ${ }^{50}$ However, carrying out such a large number of cycles was outside the timeframe of this study because of the large number of investigated materials. It can also be observed that at $1000^{\circ} \mathrm{C}$, approximately $80 \%$ of the introducing $\mathrm{SO}_{2}$ passed through the reactor and was detected by the gas analyser. At $950^{\circ} \mathrm{C}$ this decreased to nearly $40 \%$ and at $900^{\circ} \mathrm{C}$, only $10 \%$ of the introducing $\mathrm{SO}_{2}$ reached the gas analyser. Consequently, it can be readily deduced that less $\mathrm{SO}_{2}$ was adsorbed to and/or reacted with the oxygen carrier with an increase in temperature. This is in accordance with Figure 1, given the fact that the stable region of $\mathrm{CaO}$ increased with temperature, meaning that the driving force for $\mathrm{CaSO}_{4}$ or $\mathrm{CaS}$ formation was weaker at high temperatures.

Figure 7 shows the total $\mathrm{SO}_{2}$ yield, $\eta_{\mathrm{SO}_{2}}$, as a function of temperature during fuel cycles with $50 \% \mathrm{CH}_{4}$ and $0.5 \% \mathrm{SO}_{2}$ for all investigated materials at 900,950 and $1000^{\circ} \mathrm{C}$. Similar to Figure 5, it can be inferred that the amount of $\mathrm{SO}_{2}$ that passed through the reactor increased with an increase in temperature. Moreover, the total $\mathrm{SO}_{2}$ yield, $\eta_{\mathrm{SO}_{2}}$, increased with a decrease in the calcium content of the materials for both $\mathrm{Mg}$ - and $\mathrm{Mg}$ and Ti-doped materials. This could be expected since less calcium was available in the structure which could possibly result in the formation of $\mathrm{CaSO}_{4}$ or $\mathrm{CaS}$. It should be mentioned, however that this was not the case with undoped materials.

To facilitate the comparison between the reactivity of different oxygen carriers at different temperatures, the average gas yield, $\gamma_{\mathrm{CH}_{4} \text {,ave }}$ is shown in Figure 8 for all of the investigated oxygen carriers in the presence and the absence of $\mathrm{SO}_{2}$. Since $\gamma_{\mathrm{CH}_{4} \text {,ave }}$ was stable during 
reactivity testing in the absence of $\mathrm{SO}_{2}$, the $\gamma_{\mathrm{CH}_{4} \text {, ave }}$ presented in Figure 8 is the average of gas conversion during three fuel cycles in the absence of $\mathrm{SO}_{2}$. However, as shown in Figure 6, $\gamma_{\mathrm{CH}_{4}, \text { ave }}$ decreased slightly with cycling during reactivity experiments in the presence of $\mathrm{SO}_{2}$, likely as a result of sulphur deactivation. Therefore, the $\gamma_{\mathrm{CH}_{4} \text {,ave }}$ presented in Figure 8 during reactivity testing in the presence of $\mathrm{SO}_{2}$ is representative of the gas yield of the last cycle at each temperature, and not the average gas yield of all cycles at a given temperature. In Figure 8, three different effects can be discussed, i.e. the effect of calcium content, the effect of temperature and the effect of dopant, both during reduction in the presence and the absence of $\mathrm{SO}_{2}$. It can be seen that in the experiments in the absence of $\mathrm{SO}_{2}$, a lower calcium content in the materials generally resulted in less gas conversion. This would be expected since less $\mathrm{CaMnO}_{3-\delta}$ is expected to be formed during synthesis in those materials. In the presence of $\mathrm{SO}_{2}$, the drop in gas conversion for oxygen carriers with lower calcium content was also less for the undoped and Mg-doped materials. This could be anticipated, too, due to less chance for $\mathrm{CaSO}_{4}$ or $\mathrm{CaS}$ formation in samples with a lower calcium content. This can also be asserted by their higher total $\mathrm{SO}_{2}$ yield, $\eta_{\mathrm{SO}_{2}}$, as shown in Figure 7, compared to materials with higher calcium content. However, this was not the case for the doubly Mg and Ti-doped materials. Instead, for these materials it was possible to maintain a lower drop in reactivity for materials with higher calcium content, despite their lower total $\mathrm{SO}_{2}$ yield, $\eta_{\mathrm{SO}_{2}}$, as shown in Figure 7. It is unclear at this point, whether this could be attributed to the substitution of the $\mathrm{B}$-site with $\mathrm{Ti}$ in these materials, consequently this requires additional study of the interaction of different perovskite-structured materials and sulphur species. The reactivity of most of the oxygen carriers increased with temperature both in the presence and the absence of $\mathrm{SO}_{2}$. However, it was also clear that reactivity decreased in the presence of $\mathrm{SO}_{2}$ for all of the investigated oxygen carriers. The drop in reactivity increased at lower temperatures and could be as large as $50 \%$ at $900^{\circ} \mathrm{C}$, whereas at $1000^{\circ} \mathrm{C}$, the largest decrease in reactivity was about $20 \%$. This again can be ascribed to the lower thermodynamic favourability of $\mathrm{CaSO}_{4}$ or $\mathrm{CaS}$ formation at higher temperatures, as shown in Figure 1.

Since increasing the temperature had a more notable effect on the decrease in sulphur deactivation, additional experiments for the reactivity of three oxygen carriers were carried out at $1050^{\circ} \mathrm{C}$, which are summarized in Figure 9. It is easily seen that at $1050^{\circ} \mathrm{C}$, the decrease in reactivity following reduction in the presence of $\mathrm{SO}_{2}$ became minimal at only $1 \%$. Furthermore, the doubly $\mathrm{Mg}$ and Ti-doped material exhibited a lower decrease in reactivity in 
the presence of $\mathrm{SO}_{2}$ compared to undoped and singly $\mathrm{Mg}$-doped materials. The total $\mathrm{SO}_{2}$ yield, $\eta_{\mathrm{SO}_{2}}$, at $1050^{\circ} \mathrm{C}$ could reach as high as 0.94 . Experiments at even higher temperatures (e.g. $1100^{\circ} \mathrm{C}$ ), could possibly result in a total $\mathrm{SO}_{2}$ yield, $\eta_{\mathrm{SO}_{2}}$, of 1 , and consequently entirely avoid any sulphur deactivation. However, it should be mentioned that a slight deactivation in the reactivity of $\mathrm{C} 50 \mathrm{MMg}$ in the absence of $\mathrm{SO}_{2}$ has been reported already at $1050^{\circ} \mathrm{C},{ }^{33}$ which could become more severe at $1100^{\circ} \mathrm{C}$.

\subsection{Mechanisms of sulphur reaction with the oxygen carriers}

Possible mechanisms for the reaction of sulphur with the investigated perovskite-structured materials are discussed in the following. The first possible mechanism could be that $\mathrm{CaS}$ is formed during the reduction period via similar reactions to Eq. (10) and (11), given the highly reducing potential of $\mathrm{CH}_{4}$, in accordance with Figure 1. However, in the inert period following reduction, $\mathrm{SO}_{2}$ could be seen in the effluent, as shown in Figure 5, despite the absence of any oxygen which could possibly oxidize $\mathrm{CaS}$ to $\mathrm{CaO}$ and $\mathrm{SO}_{2}$, via Eq. (2). This suggests that this mechanism cannot solely describe the formation of $\mathrm{SO}_{2}$ in the inert period subsequent to reduction and instead $\mathrm{CaSO}_{4}$ must be the source for the release of $\mathrm{SO}_{2}$.

Another possible pathway could be that $\mathrm{CaS}$ reacts with $\mathrm{CaSO}_{4}$ via Eq. (12) resulting in the formation of $\mathrm{SO}_{2}$. This in particular could be valid in the later cycles after $\mathrm{CaSO}_{4}$ had already formed in the material during earlier methane cycles in the presence of $\mathrm{SO}_{2}$. However, this was not the case, since a similar concentration profile for $\mathrm{SO}_{2}$ as shown in Figure 5, was also seen in the inert period of the first methane cycle in the presence of $\mathrm{SO}_{2}$ at $1000^{\circ} \mathrm{C}$, for which there was no $\mathrm{CaSO}_{4}$ in the material from the beginning. Nevertheless, it may be possible that both $\mathrm{CaS}$ and $\mathrm{CaSO}_{4}$ were formed during a reduction period. As shown in the early part of the reduction phase in Figure 5, some oxygen was present in the bed which could favour the formation of $\mathrm{CaSO}_{4}$, while in the later part of the reduction, CaS formation was more favoured due to the absence of oxygen, see Figure 1.

It is worth noting that even $4 \mathrm{~h}$ inert $\left(\mathrm{N}_{2}\right)$ gas cycles for $\mathrm{C} 45 \mathrm{M}$ did not show any $\mathrm{SO}_{2}$ in the off-gas, which could indicate the spontaneous decomposition of $\mathrm{CaSO}_{4}$ following several methane cycles in the presence of $\mathrm{SO}_{2}$. This indicates that a sufficiently reducing environment is required to allow $\mathrm{CaSO}_{4}$ to decompose. Thus, a third mechanism could be that the presence of a highly reduced bed material, e.g. $\mathrm{CaMnO}_{2}$ or $\mathrm{CaMnO}_{2.5}$, following the reduction period, increases the reducing potential in the reactor in the subsequent inert period, thus enforcing $\mathrm{CaSO}_{4}$ to decompose. It is likely that the deactivation and subsequent partial regeneration of 
the perovskite-type oxygen carriers occurred via either the second or the third mechanism or a combination of both. Both mechanisms can be seen as the decomposition of $\mathrm{CaSO}_{4}$, the reversed Eq. (4), made possible by the presence of compounds that can readily react with any surplus of oxygen, e.g. $\mathrm{CaMnO}_{2}, \mathrm{CaMnO}_{2.5}$ or $\mathrm{CaS}$. It can be speculated that such reactions may be facilitated by the high oxygen conductivity typical of perovskite materials.

\subsection{Regeneration of the oxygen carriers following deactivation with $\mathrm{SO}_{2}$}

Figure 1 also implies that the perovskite-type oxygen carrier may be regenerable since $\mathrm{CaSO}_{4}$ can decompose to $\mathrm{CaO}$ and $\mathrm{SO}_{2}$, where $\mathrm{CaO}$ can react again with $\mathrm{Mn}_{3} \mathrm{O}_{4}$ and reconstruct the $\mathrm{CaMnO}_{3-\delta}$ phase. In this set of experiments, the $\mathrm{C} 45 \mathrm{M}$ oxygen carrier which had already been subjected to 43 fuel cycles in the presence of $\mathrm{SO}_{2}$ and as a result, the reactivity had decreased substantially compared to experiments in the absence of $\mathrm{SO}_{2}$, was used to investigate the potential for regeneration. Figure 10 shows the $\gamma_{\mathrm{CH}_{4} \text {,ave }}$ as a function of cycle number at $1000^{\circ} \mathrm{C}$ in different conditions. The experiment consisted of seven fuel cycles with a considerably longer second inert period $(\sim 40 \mathrm{~min})$ in the absence of $\mathrm{SO}_{2}$. The rationale for using a longer second inert period was to decompose as much $\mathrm{CaSO}_{4}$ as possible. It can be observed that the $\gamma_{\mathrm{CH}_{4} \text {,ave }}$ increased to approximately that of the experiment without the presence of $\mathrm{SO}_{2}$ from the beginning, thus showing that the oxygen carrier could be regenerated. Similar observations have been reported for the partial regeneration of $\mathrm{LaFe}_{0.8} \mathrm{Cu}_{0.2} \mathrm{O}_{3}$ catalysts in $5 \% \mathrm{H}_{2}$ in $\mathrm{Ar}^{42}$ When $\mathrm{SO}_{2}$ was again included in the reduction period, see cycles eight and nine, the reactivity decreased in a manner similar to that shown in Figure 8.

\subsection{Attributes of the oxygen carriers before and after reactivity tests}

Table 4 summarizes the physical and chemical characteristics of the investigated oxygen carrier particles before and after the reactivity testing. There was no significant change in the density and BET specific surface area of the particles and the observed minor changes can be considered as being within the margin of error for the methods used.

The oxygen capacity, $R_{O}$, for CLOU for most of the materials except those containing $\mathrm{Mg}$ and $\mathrm{Ti}$ were nearly constant at approximately $1 \%$, irrespective of the calcium content. However, for the doubly Mg and Ti-doped oxygen carriers, the oxygen capacity for CLOU increased with the calcium content. This could indicate that the effect of Ti substitution in these materials is more pronounced in increasing the oxygen non-stoichiometry. 
There was no change in the crystalline phase of any of the oxygen carriers after the reactivity test compared to their fresh counterparts, as determined with the XRD analysis. Figure 11 shows the XRD signatures of fresh and used samples as well as the signature after reactivity testing in the presence of $\mathrm{SO}_{2}$ for $\mathrm{C} 40 \mathrm{MMg}$. In the case of used particles after reactivity testing in the presence of $\mathrm{SO}_{2}$, no characteristic peaks could be attributed to $\mathrm{CaSO}_{4}$ or $\mathrm{CaS}$. This is not surprising given the low number of sulphur deactivation cycles, since it has been reported that a large of number of cycles are needed in order to readily observe peaks associated with $\mathrm{CaSO}_{4}$ during the deactivation of perovskite-structured materials with $\mathrm{SO}_{2}{ }^{39}$ However, the intensity of the characteristic peaks for marokite $\left(\mathrm{CaMn}_{2} \mathrm{O}_{4}\right)$ increased with a concomitant decrease in the intensity for peaks associated with the active perovskite, e.g. $\mathrm{CaMnO}_{3-\delta}$, in all samples following reactivity testing both in the presence and absence of $\mathrm{SO}_{2}$. In all $\mathrm{Mg}$-containing samples, $\mathrm{MgO}$ was also found as a separate phase, and was not incorporated into the perovskite structure, most likely due to a mismatch in the ionic radii of $\mathrm{Mg}$ and that of $\mathrm{Mn},{ }^{60}$ which has also been reported elsewhere ${ }^{32,}{ }^{33},{ }^{36}$ for $\mathrm{CaMn}_{0 .} \mathrm{Mg}_{0.1} \mathrm{O}_{3-\delta}$ (C50MMg).

The ESEM images of fresh and used samples after reactivity testing in the presence and absence of $\mathrm{SO}_{2}$ for the C43MTMg material are shown in Figure 12. The porosity and morphology of the particles did not seem to have been affected after the reactivity test. This was valid for all of the oxygen carriers investigated here.

Partial EDX analysis of the surface of the fresh and used samples after reactivity testing in the presence and absence of $\mathrm{SO}_{2}$ is shown in Figure 13. Following the reactivity experiments in the presence of $\mathrm{SO}_{2}$, a uniform distribution of the sulphur element could be found on the surface of the materials in addition to the inherent elements of the oxygen carrier, i.e. calcium, titanium, magnesium, manganese and oxygen. However, analysis of the bulk cross sections did not show the presence of the sulphur element, despite reports of the complete destruction of the perovskite bulk catalysts when deactivated with $\mathrm{SO}_{2} \cdot{ }^{40-42}$ This could be again attributed to the low number of reactivity cycles in the presence of $\mathrm{SO}_{2}$ in this study.

Only a few of the materials prepared in this study showed reasonable mechanical stability, as indicated by the crushing strength measured prior to the reactivity tests shown in Table 4. Figure 14 shows the rate of attrition of the used oxygen carriers in a jet-cup attrition rig for 1 h. In Table 5, the attrition index, $A_{i}$, defined as the slope of the attrition in the last 30 minutes of the test period, is shown for the oxygen carriers investigated. It can be seen that most of the investigated oxygen carriers have very similar attrition rates and are in an order similar to 
$\mathrm{CaMn}_{0.9} \mathrm{Mg}_{0.1} \mathrm{O}_{3-\delta} \quad(\mathrm{C} 50 \mathrm{MMg})$ which has shown excellent functionality in continuous operation in a $10 \mathrm{~kW}$ unit. ${ }^{36}$ Consequently, equally good results could be expected for these materials. Nevertheless, experiments in continuous operation are required for confirmation.

\section{Conclusion}

Perovskite-structured oxygen carriers of the type $\mathrm{Ca}_{\mathrm{x}} \mathrm{Mn}_{1-\mathrm{y}} \mathrm{M}_{\mathrm{y}} \mathrm{O}_{3-\delta}(\mathrm{M}=\mathrm{Mg}, \mathrm{Ti})$ were investigated for the CLOU process. The materials were prepared by spray drying, and the experiments were carried out in a batch fluidized-bed to evaluate the influence of calcium content, dopants (Mg and Ti) and operating temperature $\left(900,950,1000\right.$ and $\left.1050^{\circ} \mathrm{C}\right)$ on the oxygen uncoupling property and the reactivity of oxygen carriers with $\mathrm{CH}_{4}$ in the presence and absence of $\mathrm{SO}_{2}$.

All of the oxygen carriers exhibited oxygen uncoupling behaviour. Their reactivity with methane was high and increased with temperature and calcium content, approaching complete gas yield at $1000^{\circ} \mathrm{C}$. The reactivity decreased in the presence of $\mathrm{SO}_{2}$ for all of the investigated oxygen carriers. Decreasing the calcium content in the materials generally resulted in less of decrease in reactivity in the presence of $\mathrm{SO}_{2}$, with the exception of materials doped with both $\mathrm{Mg}$ and $\mathrm{Ti}$, where a higher resistance to sulphur deactivation could be maintained even at a higher calcium content. The drop in reactivity in the presence of $\mathrm{SO}_{2}$ also decreased at higher temperatures and at $1050^{\circ} \mathrm{C}$, the decrease in the reactivity of the $\mathrm{Mg}$ and Ti-doped material was minimal. Sulphur balance over the reactor system indicated that the fraction of the introduced $\mathrm{SO}_{2}$ that passed through the reactor increased with temperature. It was shown that it is possible to regenerate the oxygen carriers during reduction in the absence of $\mathrm{SO}_{2}$. Most of the developed materials also showed relatively low attrition rates. Nevertheless, achieving higher sulphur tolerant perovskite-type oxygen carriers requires further study.

\section{Acknowledgments}

The research leading to these results has received funding from the European Research Council under the European Union's Seventh Framework Programme (FP7/2007-2013) / ERC grant agreement $n^{\circ} 291235$. The authors also wish to acknowledge Chalmers University of Technology via the Energy Area of Advance for financial support for this research.

\section{References}

(1) Lewis, K. W.; Gilliland, E. R.; Sweeney, M. P. Gasification of Carbon Metal Oxides in a Fluidized Powder Bed. Chem. Eng. Prog. 1951, 47 (5), 251-256. 
(2) Ishida, M.; Jin, H. A Novel Chemical-Looping Combustor without $\mathrm{NO}_{\mathrm{x}}$ Formation. Ind. Eng. Chem. Res. 1996, 35 (7), 2469-2472.

(3) Ishida, M.; Jin, H. A new advanced power-generation system using chemical-looping combustion. Energy 1994, 19 (4), 415-422.

(4) Lyngfelt, A.; Leckner, B.; Mattisson, T. A fluidized-bed combustion process with inherent $\mathrm{CO}_{2}$ separation; application of chemical-looping combustion. Chem. Eng. Sci. 2001, 56 (10), 3101-3113.

(5) Kronberger, B.; Johansson, E.; Löffler, G.; Mattisson, T.; Lyngfelt, A.; Hofbauer, H. A Two-Compartment Fluidized Bed Reactor for $\mathrm{CO}_{2}$ Capture by Chemical-Looping Combustion. Chem. Eng. Technol. 2004, 27 (12), 1318-1326.

(6) Lyngfelt, A. Oxygen Carriers for Chemical Looping Combustion - $4000 \mathrm{~h}$ of Operational Experience. Oil Gas Sci. Technol. 2011, 66 (2), 161-172

(7) Lyngfelt, A. Chemical looping combustion; Chapter 20 in Fluidized-bed technologies for near-zero emission combustion and gasification; Scala, F. (Ed.), Woodhead Publishing Limited: Cambridge, 2013, 895-930

(8) Lyngfelt, A. Chemical-looping combustion of solid fuels - Status of development. Appl. Energy 2014, 113, 1869-1873.

(9) Hossain, M. M.; de Lasa, H. I. Chemical-looping combustion (CLC) for inherent $\mathrm{CO}_{2}$ separations-a review. Chem. Eng. Sci. 2008, 63 (18), 4433-4451.

(10) Adanez, J.; Abad, A.; Garcia-Labiano, F.; Gayan, P.; de Diego, L. F. Progress in Chemical-Looping Combustion and Reforming technologies. Progr. Energy Combust. Sci. 2012, 38 (2), 215-282.

(11) Fan, L.-S.; Zeng, L.; Wang, W.; Luo, S. Chemical looping processes for $\mathrm{CO}_{2}$ capture and carbonaceous fuel conversion - prospect and opportunity. Energy \& Environmental Science 2012, 5 (6), 7254-7280.

(12) Brown, T. A.; Dennis, J. S.; Scott, S. A.; Davidson, J. F.; Hayhurst, A. N. Gasification and Chemical-Looping Combustion of a Lignite Char in a Fluidized Bed of Iron Oxide. Energy Fuels 2010, 24 (5), 3034-3048.

(13) Dennis, J. S.; Müller, C. R.; Scott, S. A. In situ gasification and $\mathrm{CO}_{2}$ separation using chemical looping with a Cu-based oxygen carrier: Performance with bituminous coals. Fuel 2010, 89 (9), 2353-2364.

(14) Scott, S. A.; Dennis, J. S.; Hayhurst, A. N.; Brown, T. In situ gasification of a solid fuel and $\mathrm{CO}_{2}$ separation using chemical looping. AIChE J. 2006, 52 (9), 3325-3328.

(15) Leion, H.; Mattisson, T.; Lyngfelt, A. Solid fuels in chemical-looping combustion. Int. J. Greenhouse Gas Control 2008, 2 (2), 180-193.

(16) Leion, H.; Mattisson, T.; Lyngfelt, A. The use of petroleum coke as fuel in chemicallooping combustion. Fuel 2007, 86 (12-13), 1947-1958.

(17) Mattisson, T.; Lyngfelt, A.; Leion, H. Chemical-looping with oxygen uncoupling for combustion of solid fuels. Int. J. Greenhouse Gas Control 2009, 3 (1), 11-19.

(18) Abad, A.; Adánez-Rubio, I.; Gayán, P.; García-Labiano, F.; de Diego, L. F.; Adánez, J. Demonstration of chemical-looping with oxygen uncoupling (CLOU) process in a $1.5 \mathrm{~kW}_{\text {th }}$ continuously operating unit using a Cu-based oxygen-carrier. Int. J. Greenhouse Gas Control 2012, 6, 189-200.

(19) Gayán, P.; Adánez-Rubio, I.; Cuadrat, A.; Mendiara, T.; Abad, A.; García-Labiano, F.; De Diego, L.; Adánez, J. Use of Chemical-Looping processes for coal combustion with $\mathrm{CO}_{2}$ capture. Energy Procedia 2013.

(20) Arjmand, M.; Keller, M.; Leion, H.; Mattisson, T.; Lyngfelt, A. Oxygen Release and Oxidation Rates of $\mathrm{MgAl}_{2} \mathrm{O}_{4}$-Supported $\mathrm{CuO}$ Oxygen Carrier for Chemical-Looping Combustion with Oxygen Uncoupling (CLOU). Energy Fuels 2012, 26 (11), 6528-6539. 
(21) Mattisson, T. Materials for Chemical-Looping with Oxygen Uncoupling. ISRN Chemical Engineering 2013, 1-19.

(22) Rydén, M.; Leion, H.; Mattisson, T.; Lyngfelt, A. Combined oxides as oxygen-carrier material for chemical-looping with oxygen uncoupling. Appl. Energy 2013, 113, 1924-1932.

(23) Imtiaz, Q.; Hosseini, D.; Müller, C. R. Review of Oxygen Carriers for Chemical Looping with Oxygen Uncoupling (CLOU): Thermodynamics, Material Development, and Synthesis. Energy Technology 2013, 1 (11), 633-647.

(24) Arjmand, M.; Hedayati, A.; Azad, A.-M.; Leion, H.; Rydén, M.; Mattisson, T. Ca $\mathrm{La}_{1-}$ ${ }_{\mathrm{x}} \mathrm{Mn}_{1-\mathrm{y}} \mathrm{M}_{\mathrm{y}} \mathrm{O}_{3-\delta}(\mathrm{M}=\mathrm{Mg}$, Ti, $\mathrm{Fe}$, or $\mathrm{Cu})$ as Oxygen Carriers for Chemical-Looping with Oxygen Uncoupling (CLOU). Energy Fuels 2013, 27 (8), 4097-4107.

(25) Fossdal, A.; Bakken, E.; Øye, B. A.; Schøning, C.; Kaus, I.; Mokkelbost, T.; Larring, Y. Study of inexpensive oxygen carriers for chemical looping combustion. Int. J. Greenhouse Gas Control 2011, 5 (3), 483-488.

(26) Sarshar, Z.; Kleitz, F.; Kaliaguine, S. Novel oxygen carriers for chemical looping combustion: $\mathrm{La}_{1-\mathrm{x}} \mathrm{Ce}_{\mathrm{x}} \mathrm{BO}_{3}(\mathrm{~B}=\mathrm{Co}, \mathrm{Mn})$ perovskites synthesized by reactive grinding and nanocasting. Energy \& Environmental Science 2011, 4 (10), 4258-4269.

(27) Sarshar, Z.; Sun, Z.; Zhao, D.; Kaliaguine, S. Development of Sinter-Resistant CoreShell $\mathrm{LaMn}_{\mathrm{x}} \mathrm{Fe}_{1-\mathrm{x}} \mathrm{O}_{3} @ \mathrm{mSiO}_{2}$ Oxygen Carriers for Chemical Looping Combustion. Energy Fuels 2012, 26 (5), 3091-3102.

(28) Readman, J. E.; Olafsen, A.; Larring, Y.; Blom, R. $\mathrm{La}_{0.8} \mathrm{Sr}_{0.2} \mathrm{Co}_{0.2} \mathrm{Fe}_{0.8} \mathrm{O}_{3-\delta}$ as a potential oxygen carrier in a chemical looping type reactor, an in-situ powder X-ray diffraction study. J. Mater. Chem. 2005, 15 (19), 1931-1937.

(29) Leion, H.; Larring, Y.; Bakken, E.; Bredesen, R.; Mattisson, T.; Lyngfelt, A. Use of $\mathrm{CaMn}_{0.875} \mathrm{Ti}_{0.125} \mathrm{O}_{3}$ as Oxygen Carrier in Chemical-Looping with Oxygen Uncoupling. Energy Fuels 2009, 23 (10), 5276-5283.

(30) Rydén, M.; Lyngfelt, A.; Mattisson, T.; Chen, D.; Holmen, A.; Bjørgum, E. Novel oxygen-carrier materials for chemical-looping combustion and chemical-looping reforming; $\mathrm{La}_{\mathrm{x}} \mathrm{Sr}_{1-\mathrm{x}} \mathrm{Fe}_{\mathrm{y}} \mathrm{Co}_{1-\mathrm{y}} \mathrm{O}_{3-\delta}$ perovskites and mixed-metal oxides of $\mathrm{NiO}, \mathrm{Fe}_{2} \mathrm{O}_{3}$ and $\mathrm{Mn}_{3} \mathrm{O}_{4}$. Int. J. Greenhouse Gas Control 2008, 2 (1), 21-36.

(31) Noorman, S.; Gallucci, F.; van Sint Annaland, M.; Kuipers, J. A. M. Experimental Investigation of Chemical-Looping Combustion in Packed Beds: A Parametric Study. Ind. Eng. Chem. Res. 2011, 50 (4), 1968-1980.

(32) Hallberg, P.; Jing, D.; Rydén, M.; Mattisson, T.; Lyngfelt, A. Chemical Looping Combustion and Chemical Looping with Oxygen Uncoupling Experiments in a Batch Reactor Using Spray-Dried $\mathrm{CaMn}_{1-\mathrm{x}} \mathrm{MxO}_{3-\delta}(\mathrm{M}=\mathrm{Ti}, \mathrm{Fe}, \mathrm{Mg})$ Particles as Oxygen Carriers. Energy Fuels 2013, 27 (3), 1473-1481.

(33) Jing, D.; Mattisson, T.; Leion, H.; Rydén, M.; Lyngfelt, A. Examination of Perovskite Structure $\mathrm{CaMnO}_{3-\delta}$ with $\mathrm{MgO}$ Addition as Oxygen Carrier for Chemical Looping with Oxygen Uncoupling Using Methane and Syngas. International Journal of Chemical Engineering 2013, 2013, 1-16.

(34) de Diego, L. F.; Abad, A.; Cabello, A.; Gayan, P.; Garcia-Labiano, F.; Adanez, J. Reduction and Oxidation Kinetics of a $\mathrm{CaMn}_{0.9} \mathrm{Mg}_{0.1} \mathrm{O}_{3-\delta}$ Oxygen Carrier for Chemical Looping Combustion. Ind. Eng. Chem. Res. 2014, 53 (1), 87-103.

(35) Rydén, M.; Lyngfelt, A.; Mattisson, T. $\mathrm{CaMn}_{0.875} \mathrm{Ti}_{0.125} \mathrm{O}_{3}$ as oxygen carrier for chemical-looping combustion with oxygen uncoupling (CLOU) - Experiments in a continuously operating fluidized-bed reactor system. Int. J. Greenhouse Gas Control 2011, 5 (2), 356-366.

(36) Källén, M.; Rydén, M.; Dueso, C.; Mattisson, T.; Lyngfelt, A. CaMn ${ }_{0.9} \mathrm{Mg}_{0.1} \mathrm{O}_{3-\delta}$ as Oxygen Carrier in a Gas-Fired $10 \mathrm{~kW}_{\text {th }}$ Chemical-Looping Combustion Unit. Ind. Eng. Chem. Res. 2013, 52 (21), 6923-6932. 
(37) Koponen, M. J.; Venäläinen, T.; Suvanto, M.; Kallinen, K.; Kinnunen, T.-J. J.; Härkönen, M.; Pakkanen, T. A. Methane conversion and $\mathrm{SO}_{2}$ resistance of $\mathrm{LaMn}_{1-\mathrm{x}} \mathrm{Fe}_{\mathrm{x}} \mathrm{O}_{3}(\mathrm{x}=$ $0.4,0.5,0.6,1)$ perovskite catalysts promoted with palladium. J. Mol. Catal. A: Chem. 2006, $258(1-2), 246-250$.

(38) Rosso, I.; Saracco, G.; Specchia, V.; Garrone, E. Sulphur poisoning of $\mathrm{LaCr}_{0.5-\mathrm{x}} \mathrm{Mn}_{\mathrm{x}} \mathrm{Mg}_{0.5} \mathrm{O}_{3} \cdot \mathrm{yMgO}$ catalysts for methane combustion. Applied Catalysis $B$ : Environmental 2003, 40 (3), 195-205.

(39) Alifanti, M.; Auer, R.; Kirchnerova, J.; Thyrion, F.; Grange, P.; Delmon, B. Activity in methane combustion and sensitivity to sulfur poisoning of $\mathrm{La}_{1-\mathrm{x}} \mathrm{Ce}_{\mathrm{x}} \mathrm{Mn}_{1-\mathrm{y}} \mathrm{Co}_{\mathrm{y}} \mathrm{O}_{3}$ perovskite oxides. Applied Catalysis B: Environmental 2003, 41 (1-2), 71-81.

(40) Zhu, Y.; Tan, R.; Feng, J.; Ji, S.; Cao, L. The reaction and poisoning mechanism of $\mathrm{SO}_{2}$ and perovskite $\mathrm{LaCoO}_{3}$ film model catalysts. Applied Catalysis A: General 2001, 209 (1-2), 71-77.

(41) Wang, H.; Zhu, Y.; Tan, R.; Yao, W. Study on the Poisoning Mechanism of Sulfur Dioxide for Perovskite $\mathrm{La}_{0.9} \mathrm{Sr}_{0.1} \mathrm{CoO}_{3}$ Model Catalysts. Catal. Lett. 2002, 82 (3-4), 199-204.

(42) Zhang, R.; Alamdari, H.; Kaliaguine, S. $\mathrm{SO}_{2}$ poisoning of $\mathrm{LaFe}_{0.8} \mathrm{Cu}_{0.2} \mathrm{O}_{3}$ perovskite prepared by reactive grinding during $\mathrm{NO}$ reduction by $\mathrm{C}_{3} \mathrm{H}_{6}$. Applied Catalysis A: General 2008, 340 (1), 140-151.

(43) Tejuca, L. G.; Fierro, J. L. G. Properties and Applications of Perovskite-Type Oxides; (Ed.), Marcel Dekker: New York, 1993,

(44) Li, W.; Dai, H.; Lieu, Y., Improving $\mathrm{SO}_{2}$ Resistence of Base Metal Perovskite Type Oxidation Catalyst. In Stud. Surf. Sci. Catal., Guczi, L.; Solymosi, f.; Tétéyi, P., Eds. Elsevier: Budapest, 1993; Vol. 75, pp 1793-1796.

(45) Rosso, I.; Saracco, G.; Specchia, V. Tackling the problem of sulfur poisoning of perovskite catalysts for natural gas combustion. Korean J. Chem. Eng. 2003, 20 (2), 222-229.

(46) Hansen, P. F. B.; Dam-Johansen, K.; Østergaard, K. High-temperature reaction between sulphur dioxide and limestone-V. The effect of periodically changing oxidizing and reducing conditions. Chem. Eng. Sci. 1993, 48 (7), 1325-1341.

(47) Fernández, M. J.; Lyngfelt, A.; Steenari, B. M. Reaction between limestone and $\mathrm{SO}_{2}$ under conditions alternating between oxidizing and reducing. The effect of the $\mathrm{SO}_{2}$ concentration. J. Inst. Energy 2000, 73 (495), 119-125.

(48) Mattisson, T.; Lyngfelt, A. The reaction between sulphur dioxide and limestone under periodically changing oxidising and reducing conditions - The effect of reducing gases. $J$. Inst. Energy 1998, 71 (489), 190-196.

(49) Bale, C. W.; Bélisle, E.; Chartrand, P.; Decterov, S. A.; Eriksson, G.; Hack, K.; Jung, I. H.; Kang, Y. B.; Melançon, J.; Pelton, A. D.; Robelin, C.; Petersen, S. FactSage thermochemical software and databases - recent developments. Calphad 2009, 33 (2), 295311.

(50) Sundqvist, S.; Leion, H.; Rydén, M.; Lyngfelt, A.; Mattisson, T. CaMn $\mathrm{Cn}_{0.875} \mathrm{Ti}_{0.125} \mathrm{O}_{3-\delta}$ as an Oxygen Carrier for Chemical-Looping with Oxygen Uncoupling (CLOU) - Solid-Fuel Testing and Sulfur Interaction. Energy Technology 2013, 1 (5-6), 338-344.

(51) Adánez-Rubio, I.; Arjmand, M.; Leion, H.; Gayán, P.; Abad, A.; Mattisson, T.; Lyngfelt, A. Investigation of Combined Supports for $\mathrm{Cu}$-Based Oxygen Carriers for Chemical-Looping with Oxygen Uncoupling (CLOU). Energy Fuels 2013, 27 (7), 3918-3927.

(52) Rydén, M.; Moldenhauer, P.; Lindqvist, S.; Mattisson, M.; Lyngfelt, A. Measuring attrition resistance of oxygen carrier particles for chemical-looping combustion with the jet cup method. Submitted for publication 2014.

(53) Arjmand, M.; Azad, A.-M.; Leion, H.; Lyngfelt, A.; Mattisson, T. Prospects of $\mathrm{Al}_{2} \mathrm{O}_{3}$ and $\mathrm{MgAl}_{2} \mathrm{O}_{4}$-Supported $\mathrm{CuO}$ Oxygen Carriers in Chemical-Looping Combustion (CLC) and 
Chemical-Looping with Oxygen Uncoupling (CLOU). Energy Fuels 2011, 25 (11), 54935502.

(54) Arjmand, M.; Azad, A.-M.; Leion, H.; Mattisson, T.; Lyngfelt, A. Evaluation of $\mathrm{CuAl}_{2} \mathrm{O}_{4}$ as an Oxygen Carrier in Chemical-Looping Combustion. Ind. Eng. Chem. Res. 2012, 51 (43), 13924-13934.

(55) Perry, R. H.; Green, D. W. Perry's Chemical Engineering Handbook; (Ed.), 7th ed.; McGraw-Hill 1997,

(56) Kunii, D.; Levenspiel, O. Fluidization Engineering; 2nd (Ed.), Butterworth-Heinemann: Boston, 1991,

(57) HSC Chemistry 5.0, Chemical Reaction and Equilibrium Software with Extensive Thermochemical Database. In Outokumpu Research Oy: Pori, Finland, 2002.

(58) Hibbert, D. B.; Tseung, A. C. C. The reduction of sulphur dioxide by carbon monoxide on a $\mathrm{La}_{0.5} \mathrm{Sr}_{0.5} \mathrm{CoO}_{3}$ catalyst. J. Chem. Technol. Biotechnol. 1979, 29 (12), 713-722.

(59) Hibbert, D. B. Reduction of Sulfur Dioxide on Perovskite Oxides. Catalysis Reviews 1992, 34 (4), 391-408.

(60) Shannon, R. D. Revised effective ionic radii and systematic studies of interatomic distances in halides and chalcogenides. Acta Crystallographica Section A 1976, 32 (5), 751767. 


\section{Tables}

Table 1 Possible reaction pathways in the $\mathrm{Ca}-\mathrm{S}-\mathrm{O}$ system in oxidizing and reducing ( $\mathrm{CO}$ and $\mathrm{H}_{2}$ ) environments.

\begin{tabular}{ll}
\hline \multicolumn{3}{c}{ Oxidizing conditions } \\
\hline (2) & $\mathrm{CaS}+3 / 2 \mathrm{O}_{2} \rightarrow \mathrm{CaO}+\mathrm{SO}_{2}$ \\
(3) & $\mathrm{CaS}+2 \mathrm{O}_{2} \rightarrow \mathrm{CaSO}_{4}$ \\
(4) & $\mathrm{CaO}+1 / 2 \mathrm{O}_{2}+\mathrm{SO}_{2} \rightarrow \mathrm{CaSO}_{4}$ \\
& \\
& \\
& Reducing conditions \\
\hline (5) & $\mathrm{CaSO}_{4}+\mathrm{CO} \rightarrow \mathrm{CaO}+\mathrm{SO}_{2}+\mathrm{CO}_{2}$ \\
(6) & $\mathrm{CaSO}_{4}+\mathrm{H}_{2} \rightarrow \mathrm{CaO}+\mathrm{SO}_{2}+\mathrm{H}_{2} \mathrm{O}$ \\
(7) & $\mathrm{CaSO}_{4}+4 \mathrm{H}_{2} \rightarrow \mathrm{CaO}+4 \mathrm{H}_{2} \mathrm{~S}+3 \mathrm{H}_{2} \mathrm{O}$ \\
(8) & $\mathrm{CaSO}_{4}+4 \mathrm{CO} \rightarrow \mathrm{CaS}+4 \mathrm{CO}_{2}$ \\
(9) & $\mathrm{CaSO}_{4}+4 \mathrm{H} \rightarrow \mathrm{CaS}+4 \mathrm{H}_{2} \mathrm{O}$ \\
(10) & $\mathrm{CaO}+\mathrm{SO}_{2}+3 \mathrm{CO} \rightarrow \mathrm{CaS}+3 \mathrm{CO}_{2}$ \\
(11) & $\mathrm{CaO}+\mathrm{SO}_{2}+3 \mathrm{H} \rightarrow \mathrm{CaS}+3 \mathrm{H}_{2} \mathrm{O}$ \\
(12) & $\mathrm{CaS}+3 \mathrm{CaSO}_{4} \rightarrow 4 \mathrm{CaO}+4 \mathrm{SO}_{2}$ \\
\hline
\end{tabular}

*Hydrocarbons such as $\mathrm{CH}_{4}$ could replace $\mathrm{CO}$ or $\mathrm{H}_{2}$ as a reducing agent in reactions (5)-(11).

Table 2 Oxygen carriers prepared in this study.

\begin{tabular}{|c|c|c|}
\hline Oxygen carrier ${ }^{*}$ & Nominal molar composition $^{\dagger}$ & Synthesis composition [wt.\%] \\
\hline C49M & $\mathrm{CaMnO}_{3-\delta}$ & $50.7 \% \mathrm{Mn}_{3} \mathrm{O}_{4}, 49.3 \% \mathrm{Ca}(\mathrm{OH})_{2}$ \\
\hline $\mathrm{C} 45 \mathrm{M}$ & $\mathrm{Ca}_{0.83} \mathrm{MnO}_{3-\delta}$ & $55.3 \% \mathrm{Mn}_{3} \mathrm{O}_{4}, 44.7 \% \mathrm{Ca}(\mathrm{OH})_{2}$ \\
\hline $\mathrm{C} 50 \mathrm{MMg}$ & $\mathrm{CaMn}_{0.90} \mathrm{Mg}_{0.10} \mathrm{O}_{3-\delta}$ & $46.8 \% \mathrm{Mn}_{3} \mathrm{O}_{4}, 50.5 \% \mathrm{Ca}(\mathrm{OH})_{2}, 2.7 \% \mathrm{MgO}$ \\
\hline $\mathrm{C} 46 \mathrm{MMg}$ & $\mathrm{Ca}_{0.85} \mathrm{Mn}_{0.90} \mathrm{Mg}_{0.10} \mathrm{O}_{3-\delta}$ & $50.6 \% \mathrm{Mn}_{3} \mathrm{O}_{4}, 46.4 \% \mathrm{Ca}(\mathrm{OH})_{2}, 3.0 \% \mathrm{MgO}$ \\
\hline $\mathrm{C} 43 \mathrm{MMg}$ & $\mathrm{Ca}_{0.75} \mathrm{Mn}_{0.90} \mathrm{Mg}_{0.10} \mathrm{O}_{3-\delta}$ & $53.5 \% \mathrm{Mn}_{3} \mathrm{O}_{4}, 43.3 \% \mathrm{Ca}(\mathrm{OH})_{2}, 3.1 \% \mathrm{MgO}$ \\
\hline $\mathrm{C} 40 \mathrm{MMg}$ & $\mathrm{Ca}_{0.65} \mathrm{Mn}_{0.90} \mathrm{Mg}_{0.10} \mathrm{O}_{3-\delta}$ & $56.8 \% \mathrm{Mn}_{3} \mathrm{O}_{4}, 39.9 \% \mathrm{Ca}(\mathrm{OH})_{2}, 3.3 \% \mathrm{MgO}$ \\
\hline C50MTMg & $\mathrm{CaMn}_{0.775} \mathrm{Mg}_{0.10} \mathrm{Ti}_{0.125} \mathrm{O}_{3-\delta}$ & $40.1 \% \mathrm{Mn}_{3} \mathrm{O}_{4}, 50.4 \% \mathrm{Ca}(\mathrm{OH})_{2}, 2.7 \% \mathrm{MgO}, 6.8 \% \mathrm{TiO}_{2}$ \\
\hline C46MTMg & $\mathrm{Ca}_{0.85} \mathrm{Mn}_{0.775} \mathrm{Mg}_{0.10} \mathrm{Ti}_{0.125} \mathrm{O}_{3-\delta}$ & $43.4 \% \mathrm{Mn}_{3} \mathrm{O}_{4}, 46.3 \% \mathrm{Ca}(\mathrm{OH})_{2}, 3.0 \% \mathrm{MgO}, 7.3 \% \mathrm{TiO}_{2}$ \\
\hline C43MTMg & $\mathrm{Ca}_{0.75} \mathrm{Mn}_{0.775} \mathrm{Mg}_{0.10} \mathrm{Ti}_{0.125} \mathrm{O}_{3-\delta}$ & $45.9 \% \mathrm{Mn}_{3} \mathrm{O}_{4}, 43.2 \% \mathrm{Ca}(\mathrm{OH})_{2}, 3.1 \% \mathrm{MgO}, 7.8 \% \mathrm{TiO}_{2}$ \\
\hline C40MTMg & $\mathrm{Ca}_{0.65} \mathrm{Mn}_{0.775} \mathrm{Mg}_{0.10} \mathrm{Ti}_{0.125} \mathrm{O}_{3-\delta}$ & $48.7 \% \mathrm{Mn}_{3} \mathrm{O}_{4}, 39.7 \% \mathrm{Ca}(\mathrm{OH})_{2}, 3.3 \% \mathrm{MgO}, 8.2 \% \mathrm{TiO}_{2}$ \\
\hline
\end{tabular}

${ }^{*}$ Example of nomenclature for the oxygen carriers: C46MTMg, C46: 46 wt.\% Ca(OH) $;$ M: $\mathrm{Mn}_{3} \mathrm{O}_{4} ; \mathrm{T}: \mathrm{TiO}_{2} ; \mathrm{Mg}: \mathrm{MgO}$.

$\dagger$ The nominal molar composition is an empirical composition of the samples assuming formation of perovskite-structured materials. 
Table 3 Experimental scheme used for evaluating the reactivity and oxygen release ability of the investigated materials in the presence and absence of $\mathrm{SO}_{2}$.

\begin{tabular}{cccccc}
\hline $\begin{array}{l}\text { No. of } \\
\text { cycles }\end{array}$ & Inert/reducing gas & $\begin{array}{c}\text { Time during inert } \\
\text { period for CLOU }[\mathrm{s}]\end{array}$ & $\begin{array}{c}\text { Time during } \\
\text { inert purge }[\mathrm{s}]\end{array}$ & $\begin{array}{c}\text { Time during } \\
\text { reduction period }[\mathrm{s}]\end{array}$ & $\begin{array}{c}\text { Temperature } \\
{\left[{ }^{\circ} \mathrm{C}\right]}\end{array}$ \\
\hline 3 & $50 \% \mathrm{CH}_{4}-$ balance $\mathrm{N}_{2}$ & - & 60 & 20 & 900 \\
\hline 3 & $\mathrm{~N}_{2}$ & 360 & - & - & 900 \\
\hline 3 & $50 \% \mathrm{CH}_{4}-$ balance $\mathrm{N}_{2}$ & - & 60 & - & 950 \\
\hline 3 & $\mathrm{~N}_{2}$ & 360 & 60 & - & 1000 \\
\hline 3 & $50 \% \mathrm{CH}_{4}-$ balance $\mathrm{N}_{2}$ & - & - & 20 & 1000 \\
\hline 3 & $\mathrm{~N}_{2}$ & 360 & 60 & - & 1000 \\
\hline 5 & $\begin{array}{c}50 \% \mathrm{CH}_{4}-0.5 \% \mathrm{SO}_{2}- \\
\text { balance } \mathrm{N}_{2}\end{array}$ & - & - & 20 & 950 \\
\hline 3 & $\begin{array}{c}\mathrm{N}_{2} \\
\text { balance } \mathrm{N}_{2}\end{array}$ & - & 60 & - & 950 \\
\hline 5 & $\begin{array}{c}50 \% \mathrm{CH}_{4}-0.5 \% \mathrm{SO}_{2}- \\
\mathrm{N}_{2}-0.5 \% \mathrm{SO}_{2}-\end{array}$ & - & - & 20 & 900 \\
\hline 5 & $\begin{array}{c}50 \% \mathrm{CH}_{4}-\mathrm{N}_{2} \\
\text { balance }\end{array}$ & 60 & - & 900 \\
\hline
\end{tabular}

Table 4 Physical and chemical characteristics of the investigated oxygen carriers as prepared and following reactivity testing in the absence of $\mathrm{SO}_{2}$.

\begin{tabular}{|c|c|c|c|c|c|c|}
\hline \multirow{2}{*}{$\begin{array}{l}\text { Oxygen } \\
\text { carrier }\end{array}$} & \multicolumn{2}{|c|}{ Bulk density $\left[\mathrm{g} / \mathrm{cm}^{3}\right]^{*}$} & \multicolumn{2}{|c|}{$\begin{array}{l}\text { BET specific surface } \\
\text { area }\left[\mathrm{m}^{2} / \mathrm{g}\right]^{*}\end{array}$} & \multirow{2}{*}{$\begin{array}{l}\text { Oxygen capacity } \\
\text { for CLOU at } \\
1000^{\circ} \mathrm{C}, R_{o}[\%]\end{array}$} & \multirow{2}{*}{ Crystalline phases detected by XRD } \\
\hline & Fresh & Used & Fresh & Used & & \\
\hline $\mathrm{C} 49 \mathrm{M}$ & 1.4 & 1.6 & 0.28 & 0.25 & 1.04 & $\mathrm{CaMnO}_{2.98}, \mathrm{CaMn}_{2} \mathrm{O}_{4}$ \\
\hline $\mathrm{C} 45 \mathrm{M}$ & 1.3 & 1.3 & 0.27 & 0.42 & 1.05 & $\mathrm{CaMnO}_{2.80}, \mathrm{CaMn}_{2} \mathrm{O}_{4}$ \\
\hline $\mathrm{C} 50 \mathrm{MMg}$ & 1.5 & 1.5 & 0.37 & 0.39 & 0.94 & $\mathrm{CaMnO}_{2.80}, \mathrm{CaMn}_{2} \mathrm{O}_{4}, \mathrm{MgO}$ \\
\hline $\mathrm{C} 46 \mathrm{MMg}$ & 1.4 & 1.4 & 0.25 & 0.02 & 1.00 & $\mathrm{CaMnO}_{2.97}, \mathrm{CaMn}_{2} \mathrm{O}_{4}, \mathrm{MgO}$ \\
\hline $\mathrm{C} 43 \mathrm{MMg}$ & 1.1 & 1.3 & 0.4 & 0.22 & 0.99 & $\mathrm{CaMnO}_{2.98}, \mathrm{CaMn}_{2} \mathrm{O}_{4}, \mathrm{MgO}$ \\
\hline $\mathrm{C} 40 \mathrm{MMg}$ & 0.9 & 1.0 & 0.47 & 0.57 & 0.98 & $\mathrm{CaMnO}_{2.98}, \mathrm{CaMn}_{2} \mathrm{O}_{4}, \mathrm{MgO}$ \\
\hline C50MTMg & 1.6 & 1.5 & 0.33 & 0.29 & 1.58 & $\mathrm{CaMn}_{0.7} \mathrm{Ti}_{0.3} \mathrm{O}_{2.94}, \mathrm{MgO}$ \\
\hline C46MTMg & 1.4 & 1.4 & 0.29 & 0.05 & 1.50 & $\mathrm{CaMn}_{0.7} \mathrm{Ti}_{0.3} \mathrm{O}_{2.94}, \mathrm{CaMn}_{2} \mathrm{O}_{4}, \mathrm{MgO}$ \\
\hline C43MTMg & 1.3 & 1.4 & 0.29 & 0.27 & 1.01 & $\mathrm{CaMn}_{0.7} \mathrm{Ti}_{0.3} \mathrm{O}_{2.94}, \mathrm{CaMn}_{2} \mathrm{O}_{4}, \mathrm{MgO}$ \\
\hline C40MTMg & 1.2 & 1.3 & 0.27 & 0.31 & 0.86 & $\mathrm{CaMn}_{0.7} \mathrm{Ti}_{0.3} \mathrm{O}_{2.94}, \mathrm{CaMn}_{2} \mathrm{O}_{4}, \mathrm{MgO}$ \\
\hline
\end{tabular}


Table 5 Attrition rates of the investigated oxygen carriers after reactivity testing and their corresponding crushing strength (CS) in the fresh state.

\begin{tabular}{lll}
\hline Oxygen carrier & Attrition rate, $A_{i}[\mathrm{wt} . \% / \mathrm{h}]$ & Crushing strength $(\mathrm{CS})[\mathrm{N}]$ \\
\hline $\mathrm{C} 49 \mathrm{M}$ & 3.6 & 0.47 \\
\hline $\mathrm{C} 45 \mathrm{M}$ & 10.8 & 0.42 \\
\hline $\mathrm{C} 50 \mathrm{MMg}$ & 8.4 & 1.4 \\
\hline $\mathrm{C} 46 \mathrm{MMg}$ & 4.8 & 0.30 \\
\hline $\mathrm{C} 43 \mathrm{MMg}$ & 7.8 & 0.50 \\
\hline $\mathrm{C} 40 \mathrm{MMg}$ & 3.6 & 0.23 \\
\hline $\mathrm{C} 50 \mathrm{MTMg}$ & 8.2 & 1.4 \\
\hline $\mathrm{C} 46 \mathrm{MTMg}$ & 3.6 & 1.01 \\
\hline $\mathrm{C} 43 \mathrm{MTMg}$ & 7.8 & 1.37 \\
\hline $\mathrm{C} 40 \mathrm{MTMg}$ & 6.6 & 0.73 \\
\hline
\end{tabular}




\section{Figures}

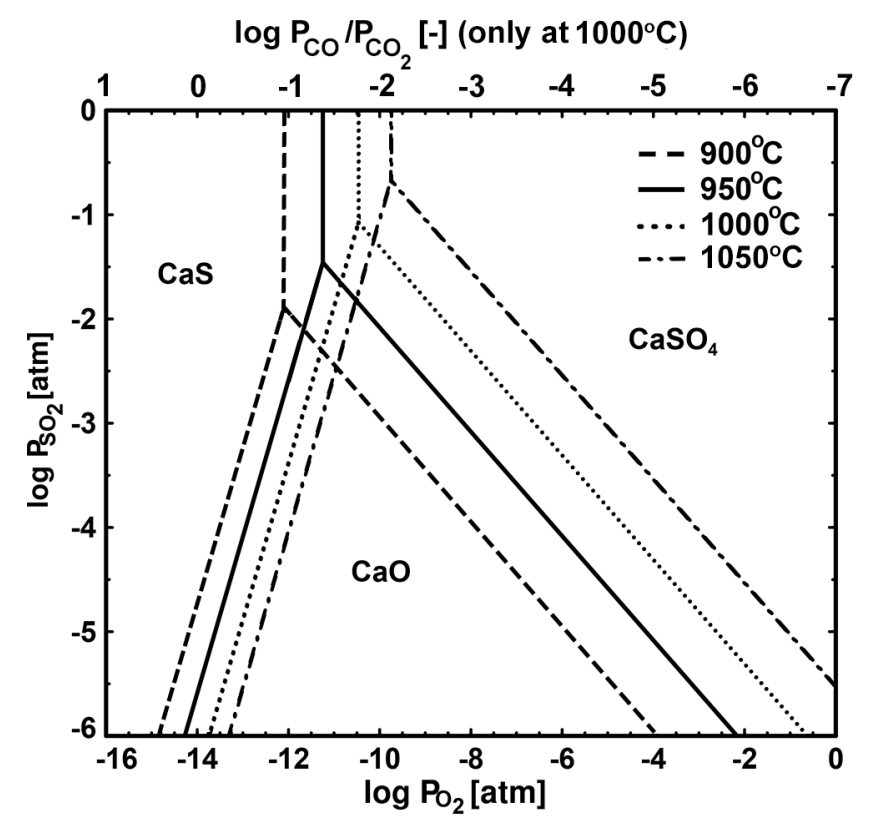

Figure 1 Predominance diagram for the system $\mathrm{Ca}-\mathrm{S}-\mathrm{O}$ showing the stability regions of $\mathrm{CaS}, \mathrm{CaSO}_{4}$ and $\mathrm{CaO}$ between 900 and $1050^{\circ} \mathrm{C}$. The $\mathrm{CO} / \mathrm{CO}_{2}$ ratio corresponding to the $\log P_{O_{2}}$ at $1000^{\circ} \mathrm{C}$ is also shown in the diagram.

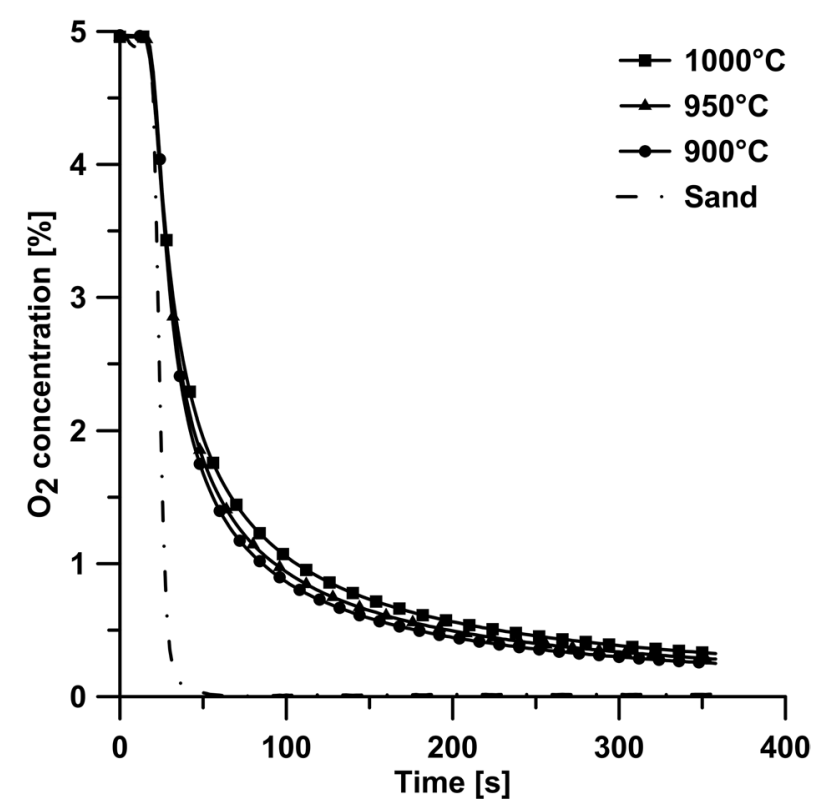

Figure 2 Oxygen profiles for inert cycle at 900,950 and $1000^{\circ} \mathrm{C}$ using $\mathrm{C} 46 \mathrm{MTMg}$ as bed material. 

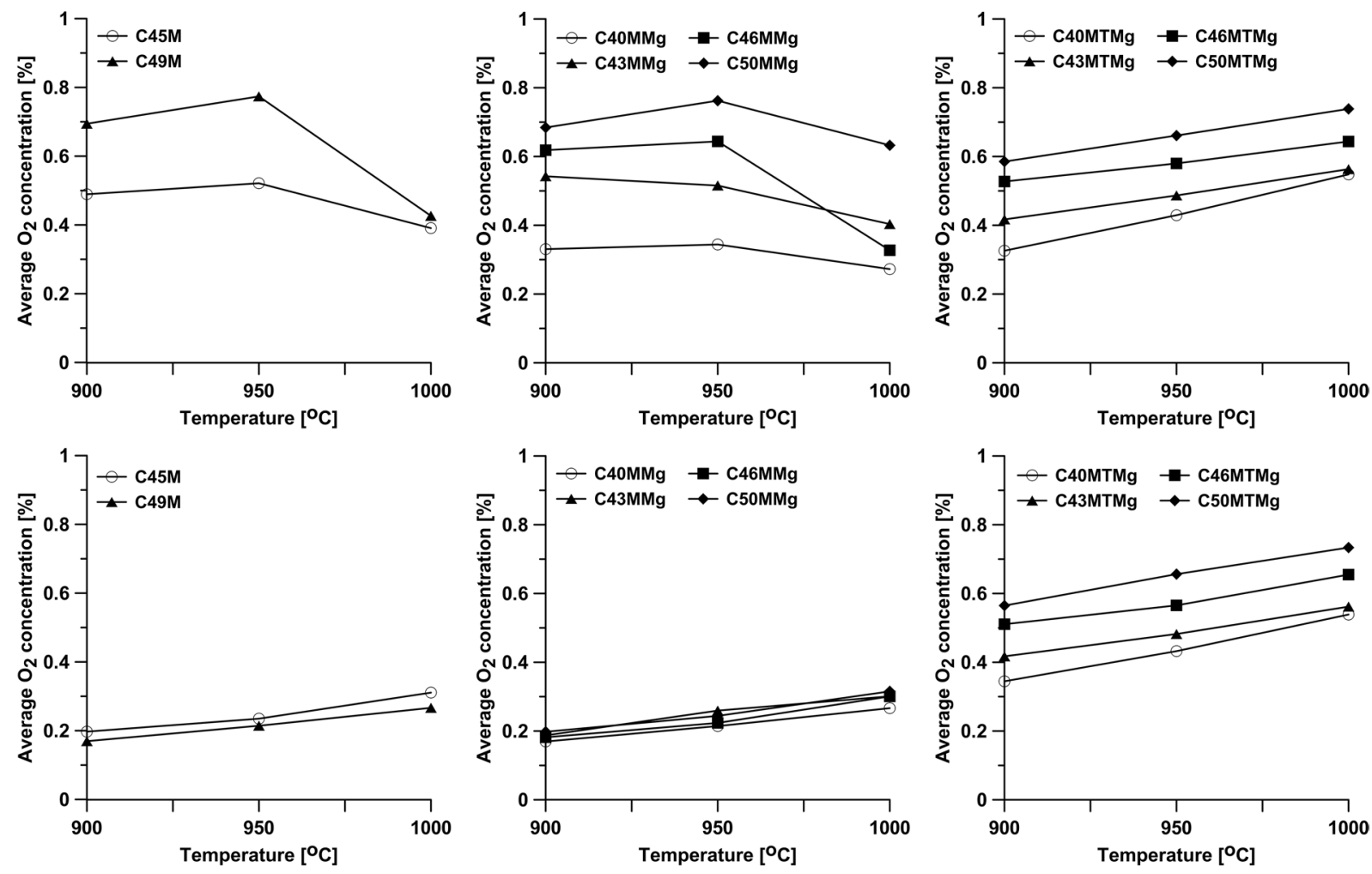

Figure 3 Average oxygen concentration as function of temperature during inert cycles for all investigated oxygen carriers following fuel cycles with (upper row) $50 \% \mathrm{CH}_{4}$-rest $\mathrm{N}_{2}$ and (bottom row) $50 \% \mathrm{CH}_{4}$ and $0.5 \% \mathrm{SO}_{2}$-rest $\mathrm{N}_{2}$ at 900,950 and $1000^{\circ} \mathrm{C}$.

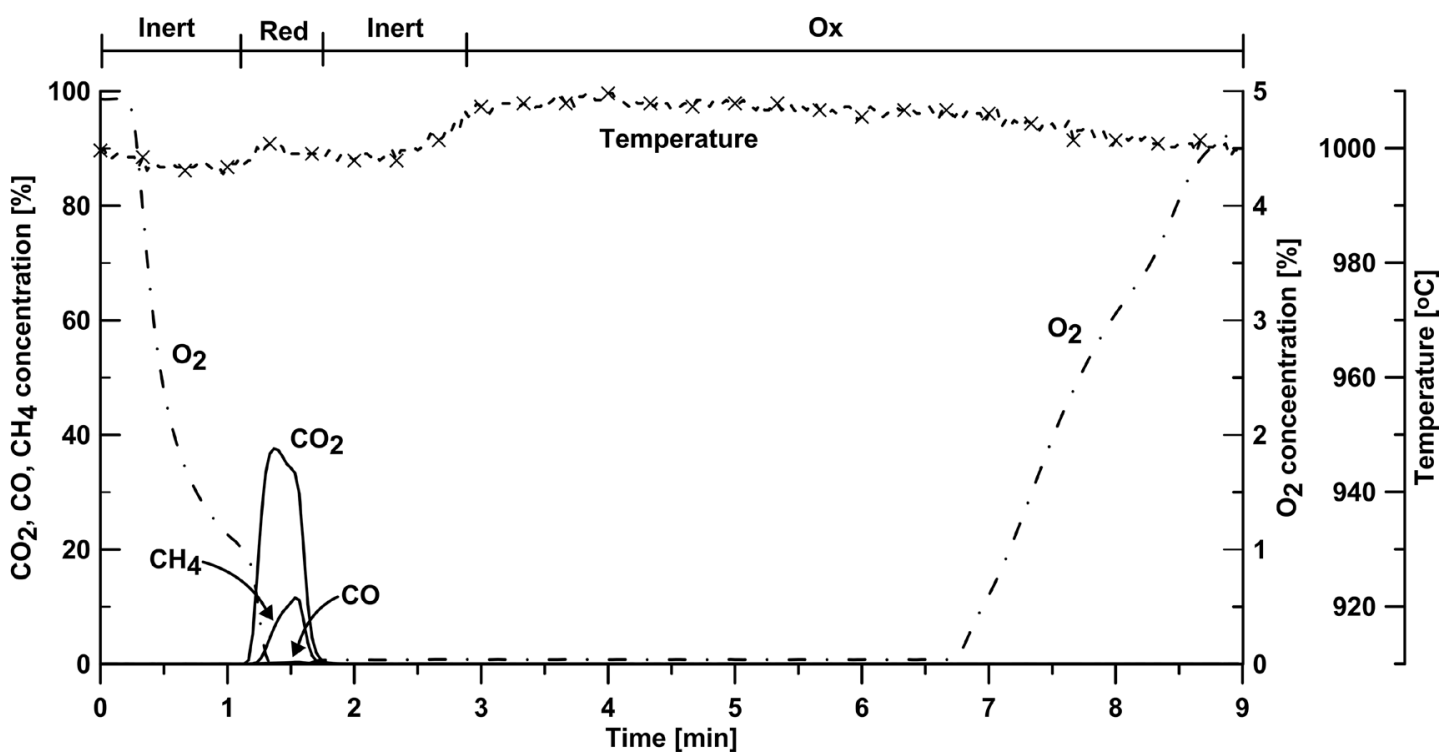

Figure 4 Gas concentration and temperature profile for C43MMg particle during third fuel cycle with $50 \% \mathrm{CH}_{4}\left(\right.$ balance $\mathrm{N}_{2}$ ) for 20 s at $1000^{\circ} \mathrm{C}$. 


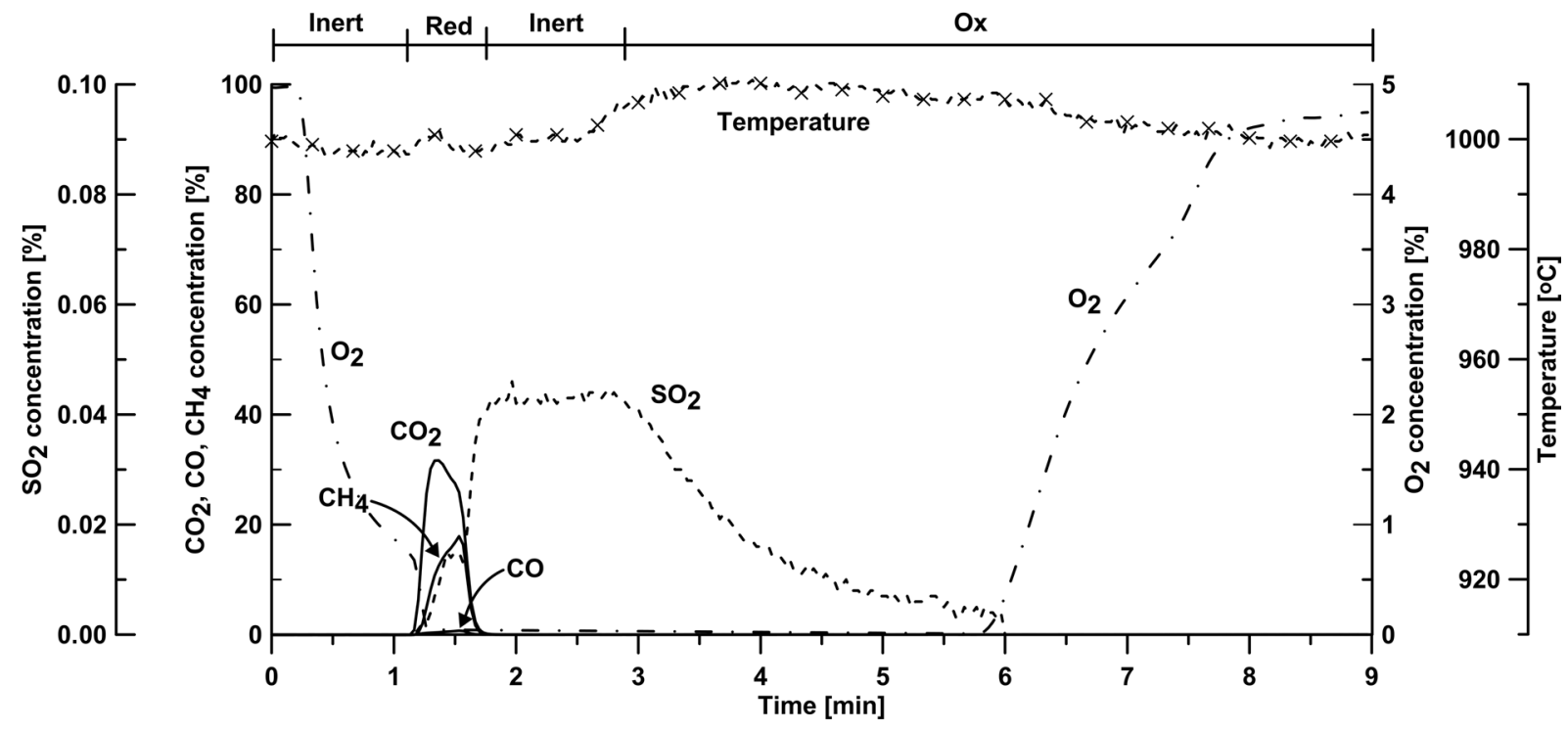

Figure 5 Gas concentration and temperature profile for C43MMg particle during fifth fuel cycle with $50 \% \mathrm{CH}_{4}$ and $0.5 \% \mathrm{SO}_{2}$-rest $\mathrm{N}_{2}$ for $20 \mathrm{~s}$ at $1000^{\circ} \mathrm{C}$.

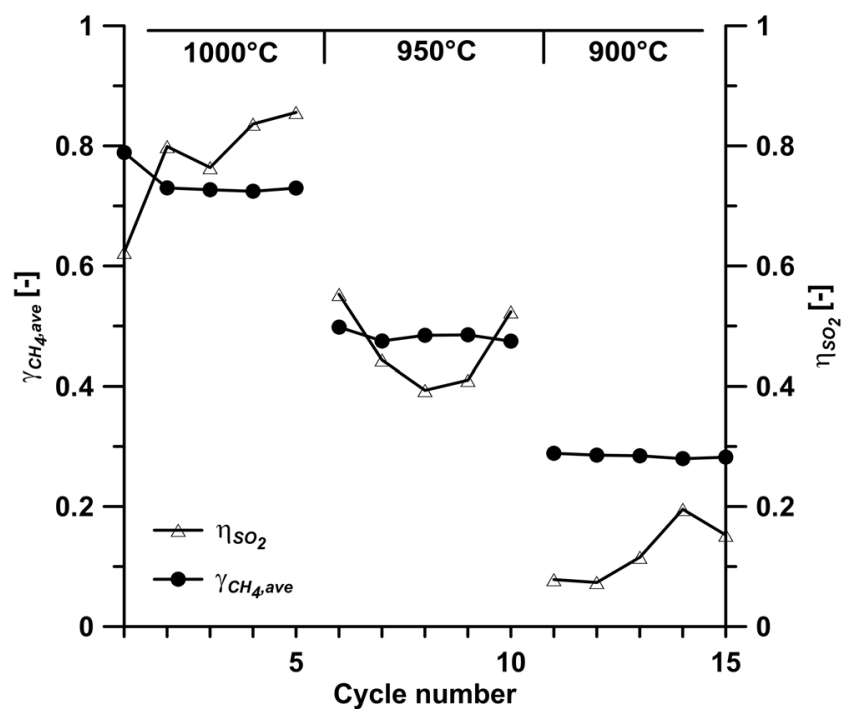

Figure 6 Average gas yield, $\gamma_{\mathrm{CH}_{4}, \text { ave }}$, and total $\mathrm{SO}_{2}$ yield, $\eta_{\mathrm{SO}_{2}}$, as function of temperature during fuel cycles with $50 \% \mathrm{CH}_{4}$ and $0.5 \% \mathrm{SO}_{2}$-rest $\mathrm{N}_{2}$ for $\mathrm{C40MTMg}$ as bed material at 900,950 and $1000^{\circ} \mathrm{C}$. 

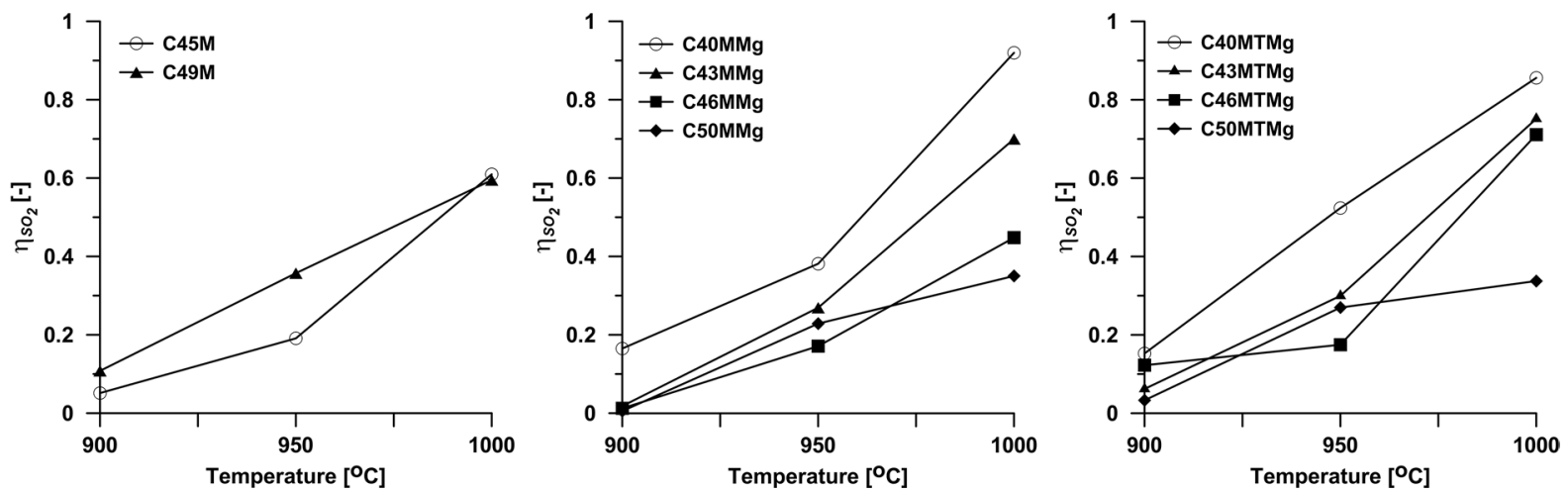

Figure 7 Total $\mathrm{SO}_{2}$ yield, $\eta_{\mathrm{SO}_{2}}$, as function of temperature during fuel cycles for all investigated oxygen carriers using $50 \% \mathrm{CH}_{4}$ and $0.5 \% \mathrm{SO}_{2}$-rest $\mathrm{N}_{2}$ at 900,950 and $100{ }^{\circ} \mathrm{C}$.
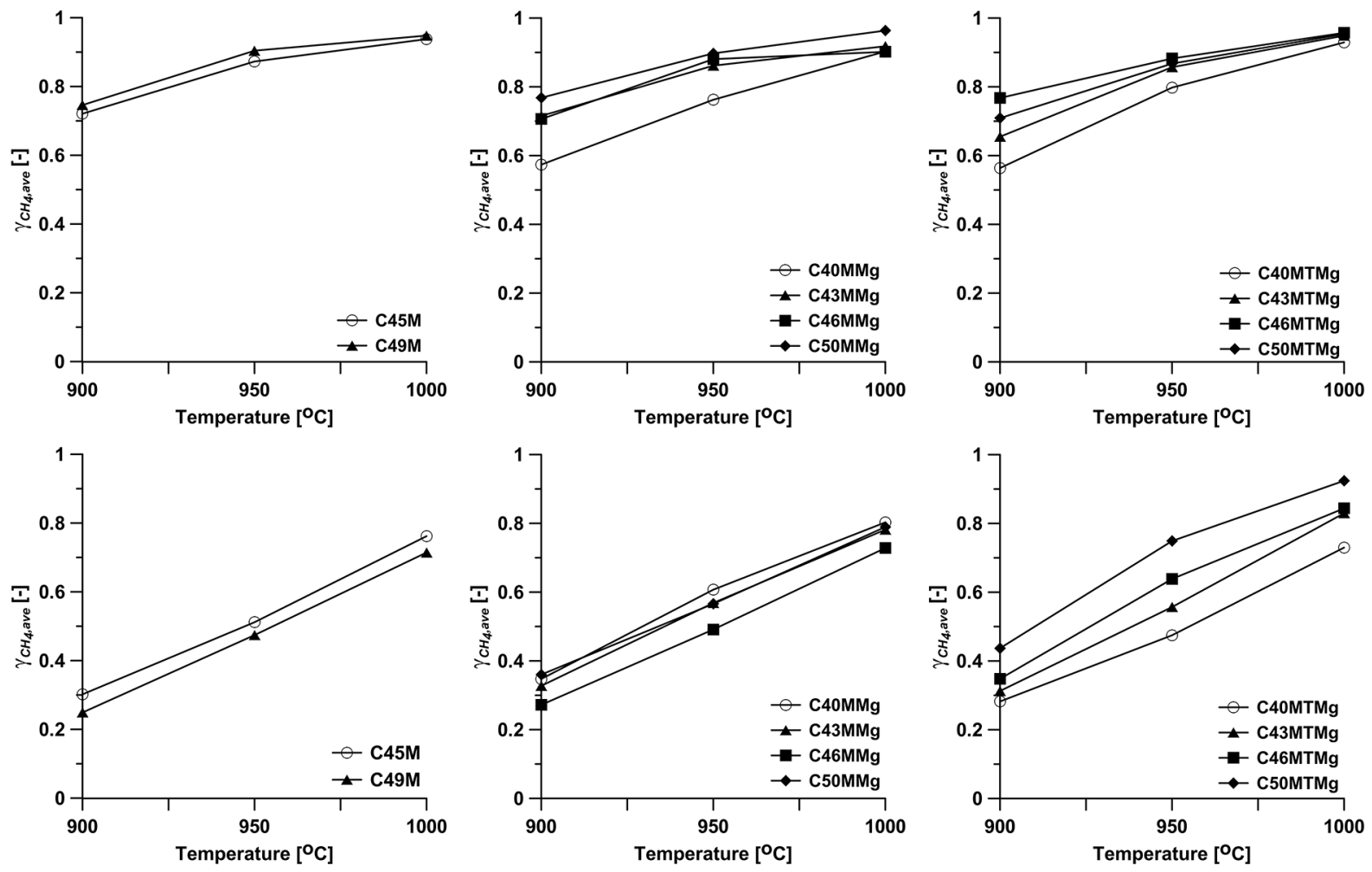

Figure 8 Average gas yield for $\mathbf{C H}_{4}, \gamma_{C_{4}, \text { ave }}$, as function of temperature during fuel cycles for all investigated oxygen carriers using (upper row) $50 \% \mathrm{CH}_{4}$-rest $\mathrm{N}_{2}$ and (bottom row) $50 \% \mathrm{CH}_{4}$ and $0.5 \%$ 

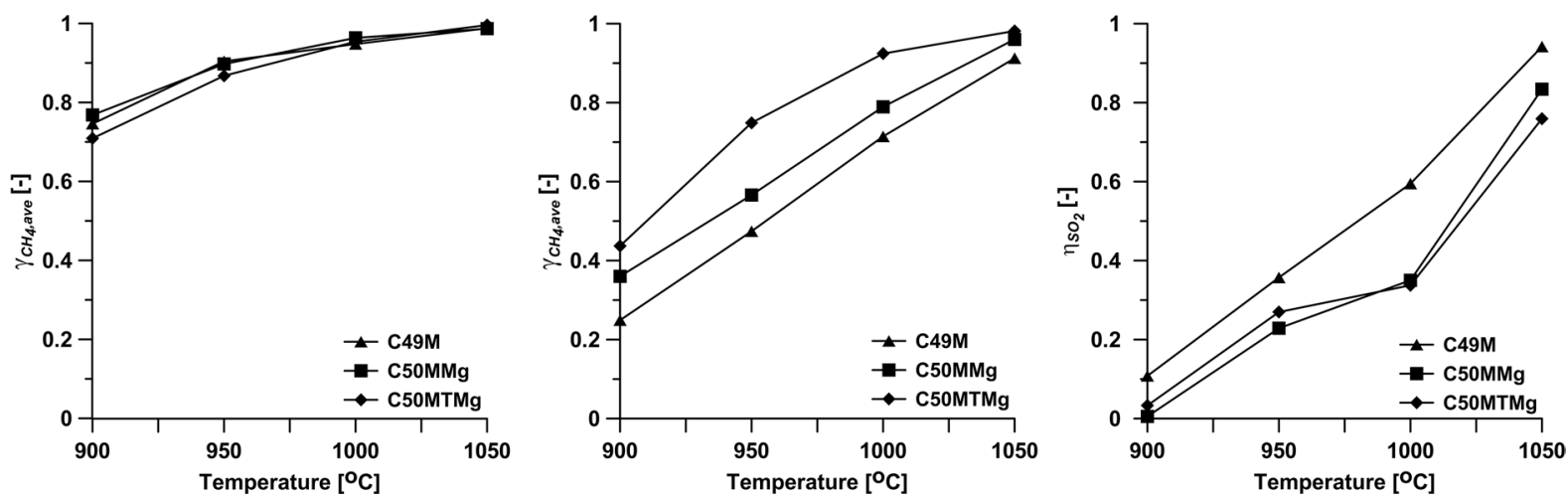

Figure 9 Average gas yield for $\mathrm{CH}_{4}, \gamma_{\mathrm{CH}_{4} \text {,ave }}$, during fuel cycles for $\mathbf{C 4 9 M}$, C50MMg and C50MTMg oxygen carriers using (left) $50 \% \mathrm{CH}_{4}$-rest $\mathrm{N}_{2}$ and (middle) $50 \% \mathrm{CH}_{4}$ and $0.5 \% \mathrm{SO}_{2}$-rest $\mathrm{N}_{2}$ and (right) their respective total $\mathrm{SO}_{2}$ yield, $\eta_{\mathrm{SO}_{2}}$, at $900,950,1000$ and $1050^{\circ} \mathrm{C}$.

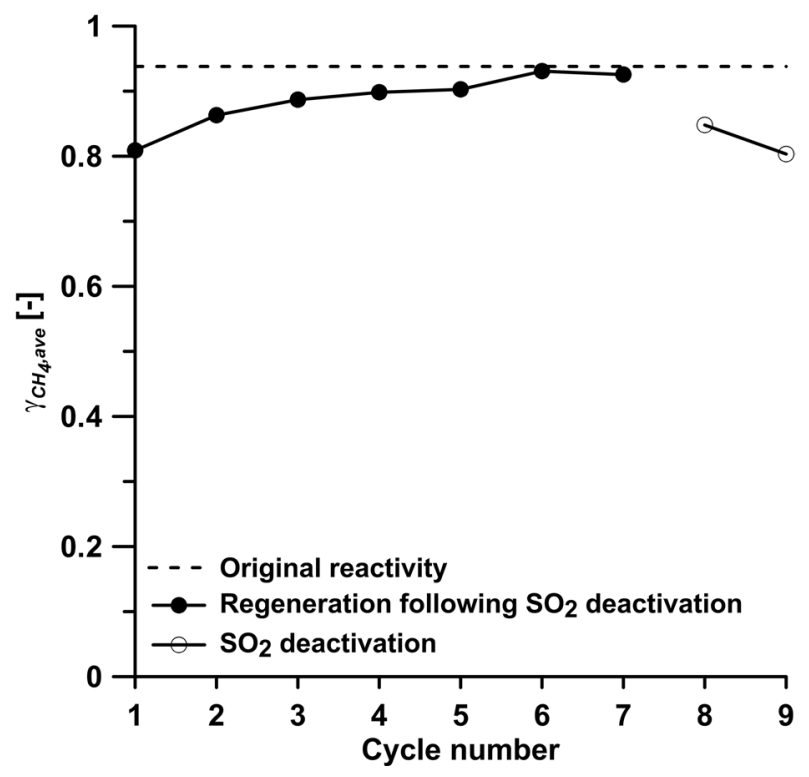

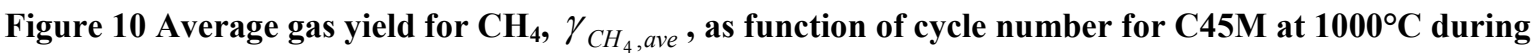
regeneration and following sulphur deactivation of oxygen carrier. 
- $\mathrm{CaMnO}_{2.97} \times \mathrm{CaMn}_{2} \mathrm{O}_{4} \quad \cdot \mathrm{MgO}$

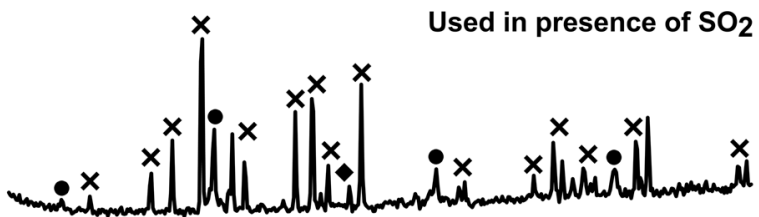

$\times \quad$ Used in absence of $\mathrm{SO}_{2}$
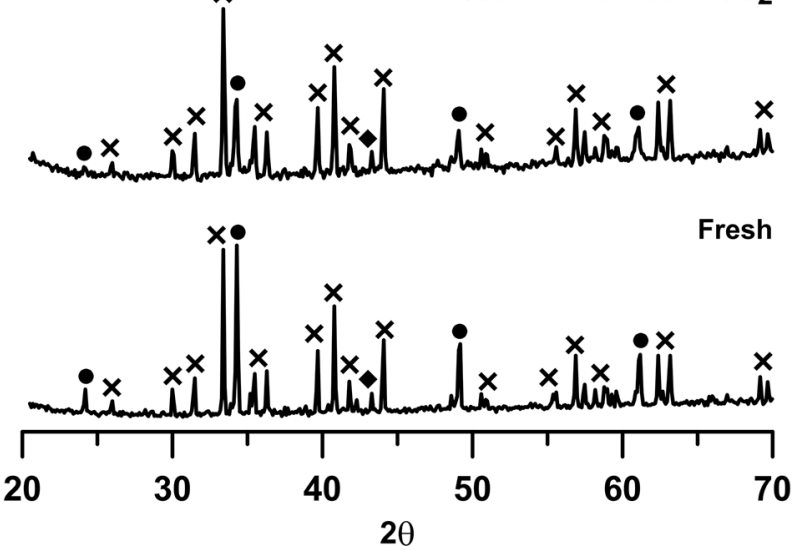

Figure 11 Comparative XRD signatures of (bottom) fresh and used in (middle) absence and (top) presence of $\mathrm{SO}_{2}$ for $\mathrm{C40MMg}$ following oxidation in $5 \% \mathrm{O}_{2}$ stream.
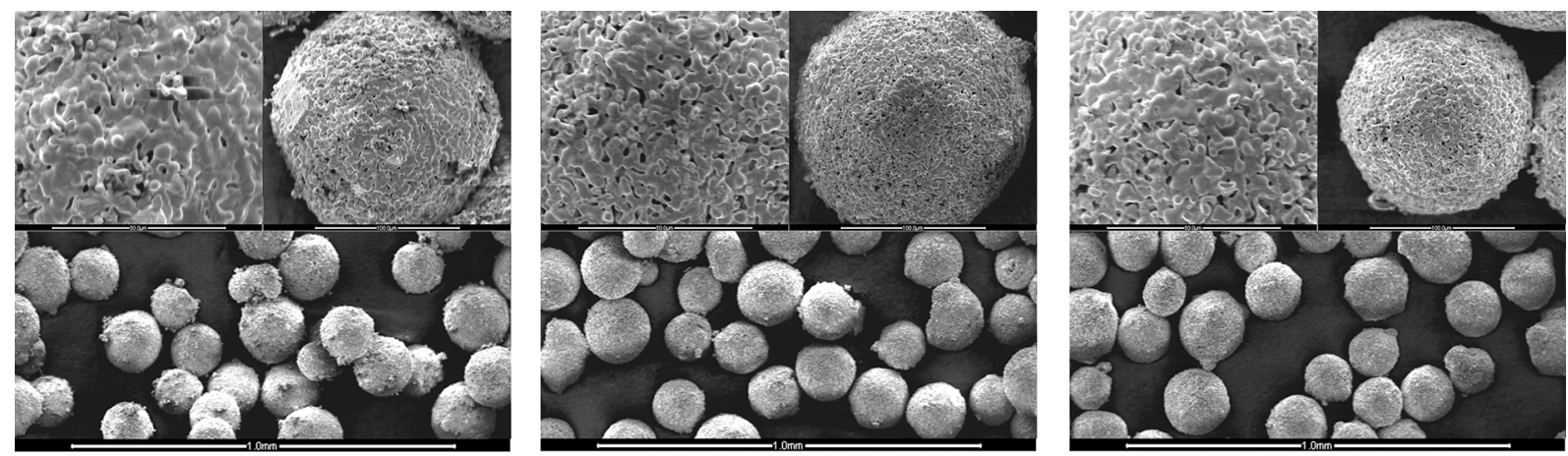

Figure 12 ESEM images of (left) fresh C43MTMg and particles subject to reactivity in the (middle) absence of $\mathrm{SO}_{2}$ and (right) presence of $\mathrm{SO}_{2}$ for particles. The size bars for the images with higher magnification are 50 and $100 \mu \mathrm{m}$, while those of the images with lower magnification are $1 \mathrm{~mm}$. 


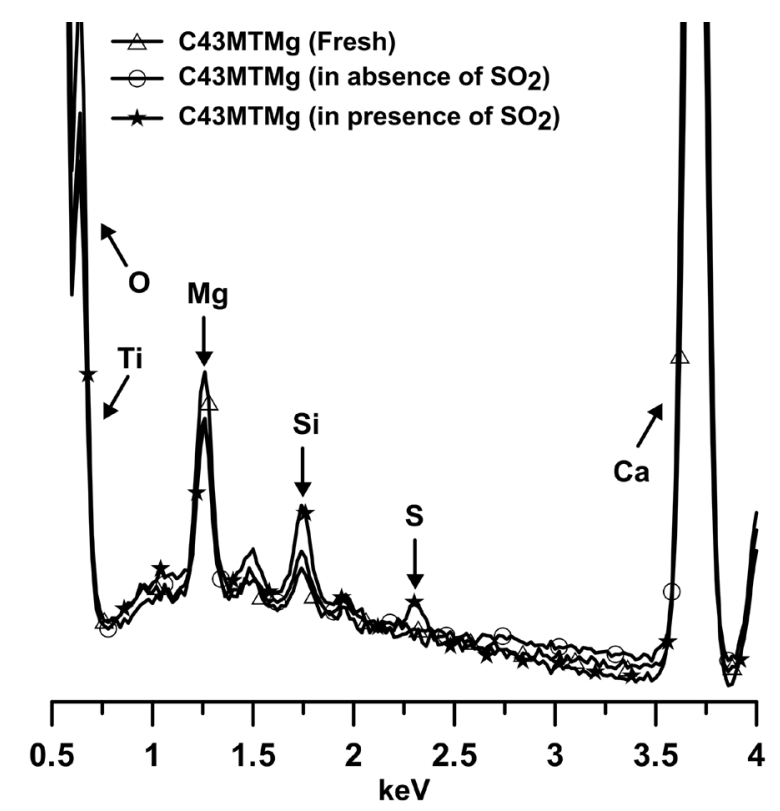

Figure 13 Partial EDX spectrums of fresh C43MTMg, and particles subject to reactivity test in absence and presence of $\mathrm{SO}_{2}$.
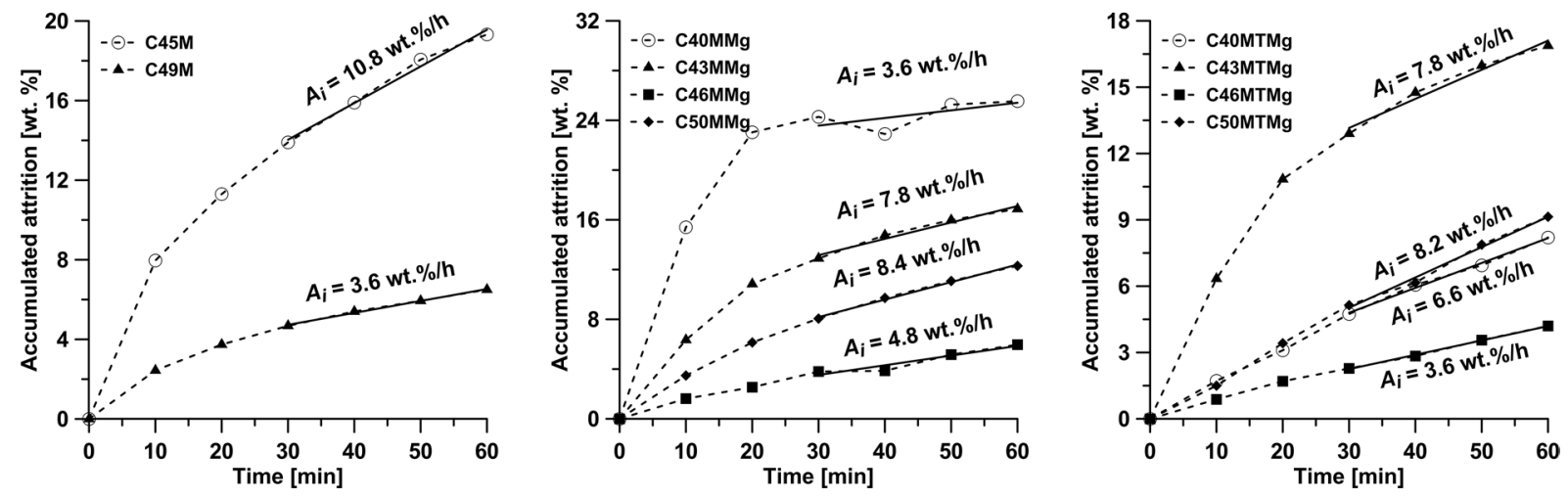

Figure 14 Accumulated attrition as a function of time for all investigated oxygen carriers. Note: For reasons of clarity, the scale of accumulated attrition is different in the figures. 